\title{
Mafic macrocrysts of ultrabasic alkaline dikes from the Mantiqueira Range, SE, Brazil: tracers of a complex plumbing system
}

\author{
Júlio César Lopes da Silva ${ }^{1,2}$ (D), Rogério Guitarrari Azzone ${ }^{1}$ (D), \\ Luanna Chmyz' (D), Vincenza Guarino ${ }^{3}$ (D), Nicholas Machado Lima ${ }^{1,2}$ (D)
}

\begin{abstract}
Macrocryst assemblages of porphyritic alkaline dikes in the Mantiqueira range (SE Brazil) are mainly composed of clinopyroxene and olivine with different origins. Based on petrographic features, mineral chemistry, and equilibrium relationships with the host liquid, those macrocrysts are classified as xenocrysts, antecrysts, and phenocrysts. Described xenocrysts are mantle olivine, Cr-diopside cores compatible with garnet-bearing mantle facies, green-core clinopyroxene cores compatible with lower crust, and enstatite cores mantled by clinopyroxene, all reported for the first time in this region. Two contrasting types of clinopyroxene antecrysts prevail among the macrocryst cores (both occurring in the same samples and presenting corrosion and sieve textures): primitive colorless diopside and more evolved green-core clinopyroxenes. In the studied rocks, green clinopyroxene zones mantling colorless diopside cores (and vice-versa) are also found. Diopside- and green-cores antecrysts have similar compositions to those from mafic and felsic alkaline melts, respectively. Phenocrysts are mainly related to Ti-augite overgrowths, mantling all other types. Mixing-model curves between mafic and felsic alkaline equilibrium liquids calculated from clinopyroxene antecrysts indicate a hybrid origin for the host matrix. The macrocryst populations of the studied dikes are indicative of a complex plumbing system, recording several processes of an open-system magmatic evolution.
\end{abstract}

KEYWORDS: clinopyroxene antecrysts; mantle xenocrysts; alkaline magmatism; complex plumbing system.

\section{INTRODUCTION}

Volcanic and subvolcanic mafic alkaline rocks result from the cooling of magmas generated by the low-degree partial melt of mantle peridotites, being this source previously metasomatized, fertile or a mixture of both (Foley 1992, Pilet et al. 2008, Laporte et al. 2014). Implications for the generation, ascent, evolution and emplacement of such igneous bodies can be predicted based on the complex petrographic and chemical features of their mineral content (Davidson et al. 2007, Ginibre et al. 2007). Mafic minerals are of special interest because they crystallize over wide temperature and pressure ranges, recording the magmatic processes from mantle source

\footnotetext{
Supplementary data

Supplementary data associated with this article can be found in the online version: Supplementary Material A, Supplementary Material B, Supplementary Material C, Supplementary Material D.
}

${ }^{1}$ Universidade de São Paulo - São Paulo (SP), Brazil. E-mails: jlopes16@ usp.br, rgazzone@usp.br,chmyz@usp.br, nicholasmachadolima@usp.br ${ }^{2}$ Programa de Pós-Graduação Geociências (Mineralogia e Petrologia), Instituto de Geociências, Universidade de São Paulo - São Paulo (SP), Brazil.

${ }^{3}$ Università di Napoli Federico II, Complesso Universitario Monte Sant'Angelo - Naples, Italy. E-mail: vincenza.guarino@unina.it

*Corresponding author: rgazzone@usp.br

(C) 2020 The authors. This is an open access article distributed under the terms of the Creative Commons license. to final consolidation at shallower lithospheric levels (Foley et al. 2011, Ubide et al. 2014a, 2015, Bussweiler et al. 2015, McGee and Smith 2016).

Olivine, clinopyroxene, amphibole, and phlogopite are the most common early mafic minerals in alkaline magmas. A number of recent studies demonstrate that such minerals are not always properly referred to as phenocrysts, once they may be in chemical disequilibrium with the host liquid (e.g., Ubide et al. 2012, Menezes et al. 2015). When foreign to the magmatic system, they are called xenocrysts; when in chemical disequilibrium, but still cognate, they are known as antecrysts, possibly formed in early stages of the magma differentiation history (Jerram and Davidson 2007).

Understanding complex texture and zonation of mineral populations of volcanic and subvolcanic rocks has contributed to the modeling of complex plumbing systems (Jerram and Martin 2008). In this model, wall-rock fragments from different lithospheric levels are embedded into the ascending magma and transported to its final emplacement site (Orejana et al. 2006, Jankovics et al. 2016). As magma ascents, it passes through different interconnected chambers and interacts with other igneous melts (Ubide et al.2014b, Gernon et al. 2016). The characteristics of each chamber may be imprinted on the zoning pattern of the mineral assemblage (growth stratigraphy) and thus revealed by petrography and in situ analyses of each of the different zones. This mechanism allows the characterization of early magmatic stages and associated processes 
(Davidson et al. 2007, Jerram and Martin 2008, Streck 2008). Petrography and mineral chemistry studies on zoned macrocrysts in porphyritic alkaline dikes have indicated open magmatic systems whose evolution involves mixtures of basic-ultrabasic and intermediate alkaline magmas (e.g., Dobosi and Fodor 1992, Rock et al. 1994, Simonetti et al. 1996, Valente 1997, Kahl et al. 2011, Jankovics et al. 2012, Gernon et al. 2016, Ubide et al. 2014a, 2014b, Batki et al. 2018) and/or incorporation of xenoliths and xenocrysts from crustal host rocks and/or lithospheric sources (e.g., Szabó and Bodnar 1998, Pilet et al. 2002, Orejana et al. 2006, 2007, Jankovics et al. 2016).

Zoned structures (i.e., aphanitic/vitreous borders followed by intermediate vesicular regions and porphyritic centers) are common to mafic alkaline dikes of the Mantiqueira Range, Serra do Mar Alkaline Province (Alves et al. 1992, Brotzu et al. 2005, Marins 2012, Menezes et al. 2015, Azzone et al. 2018). The predominantly mafic macrocrysts (1-10 mm, as with Ubide et al. 2014b) are notable for showing varied zoning styles, as well as dissolution, corrosion, diffusive re-equilibrium and recrystallization textures. Such petrographic features are indicative of a disequilibrium between crystals and their host magmatic liquids, which suggests open-system evolution processes (Davidson et al. 2007, Ginibre et al. 2007, Jerram and Davidson 2007, Streck 2008).

In the western Mantiqueira range, SE Brazil, porphyritic alkaline dikes from the Upper Cretaceous cut the Neoproterozoic basement and the contemporaneous Ponte Nova alkaline mafic-ultramafic intrusion. Mafic macrocrysts of these dikes bear evidence of distinct differentiation stages related to open- and closed-system magmatic processes (Streck 2008, Menezes et al. 2015, Azzone et al. 2018). In this scenario, the present study aims to identify, based on antecrysts, xenocrysts and phenocrysts features, the magmatic processes that operated on the ultrabasic dikes with alkaline affinity from the western Mantiqueira range.

\section{MAGMATIC CONTEXT}

Hundreds of Cretaceous alkaline and alkaline-carbonatitic occurrences recognized over the Brazilian Platform are related to the intense magmatic episodes that followed the breakdown of Gondwana. These units have been grouped into several provinces, including the Serra do Mar alkaline province (Fig. 1A; Almeida 1983), which was later subdivided by Riccomini et al. (2005) into the Northern Serra do Mar alkaline province (from the coast of São Paulo and western Mantiqueira range to the Paraná Basin border) and the Cabo Frio magmatic lineament (an alignment of alkaline occurrences from Poços de Caldas to Cabo Frio Island).

Along the Mantiqueira range, silica-undersaturated to saturated syenite varieties prevail among the alkaline rocks. Hypabissal correlatives (i.e., trachyte and phonolite) are volumetrically subordinate and occur as dikes, plugs, sills, and small stocks (Alves et al. 1992, Brotzu et al. 2005, Enrich et al. 2005, Rosa and Ruberti 2018, Azone et al. 2018, Guarino et al. 2019). Mafic and ultramafic alkaline swarms of centimeter-to-metric and mainly porphyritic dikes (occasionally zoned and/or juxtaposed) cut both the basement and the alkaline occurrences (Azzone et al. 2018). On the other hand, mafic-ultramafic rocks (cumulates) prevail in the Ponta Nova Massif, located in the western portion of the Mantiqueira range (Azzone et al. 2009a, 2009b, 2016). The Ponte Nova massif is emplaced in the metagranites of the Serra da Água Limpa Batholith, in the Socorro-Guaxupé nappe migmatites and in the metasedimentary rocks of the Embu Terrain (Fig. 1B; Vinagre et al. 2014).

The mafic alkaline dikes of the western Mantiqueira range studied here occur in the vicinities of the Ponte Nova mafic-ultramafic alkaline massif in the cities of Sapucaí Mirim (MG), Santo Antônio de Pinhal (SP), and Campos do Jordão (SP) (Fig. 1B). In situ sampling of the alkaline dikes is hampered by inaccessibility, the restricted exposure and the intense weathering in the Mantiqueira range region. Most of the unaltered samples are related to blocks collected along drainage segments throughout the escarpment and outcrops along the main roads.

\section{MATERIALS AND METHODS}

Samples of the mafic alkaline dikes were described in detail and petrography focused on the compositions and textures of macrocrysts hosted by different types of matrices. Pyroxene, olivine, amphibole, and phlogopite crystals from eight representative ultrabasic occurrences were selected for in situ chemical analysis by electron microprobe using wavelength dispersion system (WDS) and by laser ablation inductively coupled plasma mass spectrometry (LA-ICP-MS).

Electron microprobe analyses were performed at the NAP GeoAnalítica-USP Electron Microprobe Laboratory, University of São Paulo, using a JEOL JXA-FE 8530 microanalyzer with a field emission revolver coupled to five wavelength dispersion spectrometers with two crystals each. The same analytical parameters were applied to all mineral phases, i.e., $15 \mathrm{kV}$ of acceleration potential, 20 $\mathrm{A}$ of current intensity and $5 \mu \mathrm{m}$ for the beam diameter. Matrix corrections were performed with CITZAF (Armstrong 1995) and ZAF algorithms. Structural formula calculation for pyroxene, amphibole, and phlogopite followed Morimoto (1988), Gualda and Vlach (2005), and Rieder et al. (1998), respectively. For olivine, the structural formula was calculated according to Deer et al. (1992).

Quantification of minor and trace elements was also performed at the NAP Geoanalítica-USP Chemistry Laboratory, University of São Paulo, using a super cell chamber-equipped New Wave UP 213 AF ablation system. The system was coupled to a quadrupole Thermo Scientific ${ }^{\mathrm{Tx}}$ iCAP $^{\text {Tx }}$ RQICP-MS. Helium was used as a carrier gas of the ablated sample into the Ar plasma. NIST-612 (glass), BHVO (basalt), and BIR (glass) calibration standards were applied to all samples. Analytical procedures were performed according to Andrade et al. (2014). Analyses of olivine (20), pyroxene (144), amphibole (12), and phlogopite (11) were performed. Spot diameter was of $55 \mu \mathrm{m}$ for most of the analyses, but reduced in size to $40 \mu \mathrm{m}$ for smaller targets. The blank and counting periods of $60 \mathrm{~s}$ were 
applied for each analysis. Wash-out time between consecutive analyses was $30 \mathrm{~s}$. BHVO-2, BCR-2G, NIST610, and/or NIST612 were systematically analyzed for quality control and presented deviations of up to $10 \%$ off the reference values (GeoReM, preferred values; Jochum et al. 2005) for most elements, similarly to Reguir et al. (2012). Supplementary Material A details the methodology and calibration standards of the performed WDS and LA-ICP-MS analyses, in addition to the data for the analyzed minerals.

Lithogeochemical data from 8 selected dikes were compiled from Azzone et al. (2018), except for one sample (MT-75A), whose composition was quantified in the same laboratories following the same methods as the main data source. These data are presented in Supplementary Material B.

\section{RESULTS}

\section{Petrography}

The mafic dikes of Mantiqueira range are melanocratic and their mineral assemblages consist of olivine, clinopyroxene, amphibole, phlogopite, felsic minerals, opaque minerals, carbonates, and apatite. They are porphyritic rocks with grain size bimodality that identify the presence of different populations of macrocrysts $(1-10 \mathrm{~mm})$ embedded in a microcrystalline $(<1 \mathrm{~mm})$ matrix. Ocelli and amygdales are recurrent, commonly filled with the same felsic constituents as the matrix. Following IUGS recommendations (Le Maitre 2002), the investigated dikes are classified as alkali basalt, alkaline lamprophyre and phonolitic tephrite.

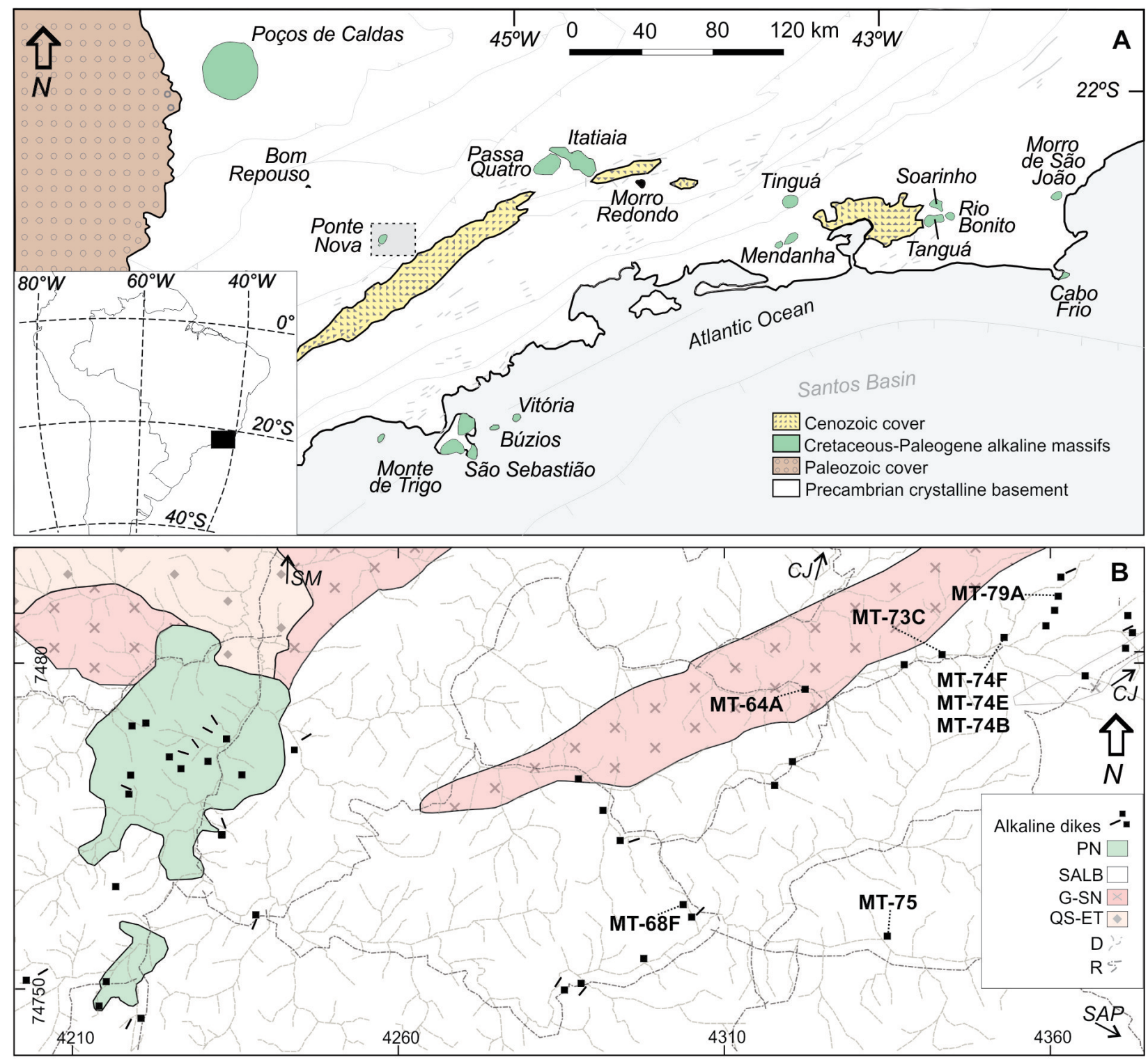

Figure 1. (A) Geological sketch map of the Serra do Mar Alkaline Province in SE Brazil, modified from Thompson et al. (1998) and Rosa and Ruberti (2018) with indication of the studied area (grey square). (B) Simplified geological map of part of the Mantiqueira mountain region (studied area). Alkaline dikes are represented by black squares (sampling point of unaltered rocks) in the main drainages (D) and by the strike direction of in situ bodies. The selected dikes for this study are identified with their sample codes. PN, Ponte Nova alkaline massif (Azzone et al. 2009a); SALB: Serra da Água Limpa Batholith; G-SN: gneisses of the Socorro Nappe; QS-ET: quartzites and schists of Embu Terrane (Precambrian basement units from Vinagre et al. 2014). R: main roadways. Reference Cities: SAP: Santo Antônio do Pinhal; CJ: Campos do Jordão; SM: Sapucaí Mirim. Extracted from Azzone et al. (2018). 
Alkali basalt consists of zoned macrocrysts of pyroxene with a glomeroporphyritic texture, subhedral to anhedral olivine (either with sieve texture or completely altered), skeletal or subhedral plagioclase and anhedral kaersutite (Fig. 2A). Although clinopyroxene generally represents the most significant macrocryst phase, olivine prevails in some samples, reaching $13 \%$ of the modal content (alkaline olivine basalt; Fig. 2B). The mafic matrix cargo is composed of zoned clinopyroxene microcrysts, as well as subordinate kaersutite and opaque minerals (ilmenite and Ti-magnetite). The predominantly felsic, thin to very thin matrix consists of plagioclase and/or alkali feldspar and small amounts of carbonate.

Two different types of panidiomorphic alkaline lamprophyres are observed: camptonite and monchiquite, which differ in their macrocryst population and matrix composition. The camptonite consists of clinopyroxene macrocrysts (locally skeletal), kaersutite and zoned phlogopite embedded in a matrix of plagioclase, alkali feldspar, and nepheline. Opaque minerals and apatite are also found as main accessory phases. The monchiquite has euhedral kaersutite as the main mafic macrocryst phase, with glomeroporphyritic texture and oscillatory zoning, and an aphanitic matrix mainly composed of nepheline (Fig. 2C).

The phonolitic tephrite is glomeroporphyritic, with zoned pyroxene macrocrysts, olivine pseudomorphs replaced by carbonate and, rarely, sector-zoned phlogopite (Fig. 2D).
Clinopyroxene, kaersutite, opaque minerals, and phlogopite constitute the mafic matrix cargo, while the felsic assemblage consists of an intergrowth of alkali feldspar with nepheline.

\section{Macrocryst populations}

The macrocryst assemblages of the investigated dikes consist mainly of olivine, clinopyroxene, kaersutite, and phlogopite in different proportions. Their diverse petrographic features allow different populations or types of macrocrysts to be identified. For the purposes of the present study, "type" corresponds to any crystal, zone or inclusion showing the petrographic and chemical signatures detailed here (these types can be smaller than the minimum size of the macrocryst themselves). These subdivisions are especially important for olivine and clinopyroxene, the main macrocrystic phases, with characteristics summarized in Table 1.

\section{Olivines}

Except for the pseudomorphs described in the phonolitic tephrite, olivine macrocrysts are restricted to alkali basalts and can be separated into two types (Figs. 3A-3D). Type- 1 olivine (up to 2 vol\%) shows rounded anhedral habit and embayment texture (Figs. 3A and 3B). They are also characterized by a normal progressive concentric zoning, with high forsterite (Fo) contents in core zones $\left(\mathrm{Fo}_{84>90}\right)$ trending towards low-Fo rims $\left(\mathrm{Fo}_{71-81}\right)$ (Tabs. A3 and A4 - Suppl. Material A). When little
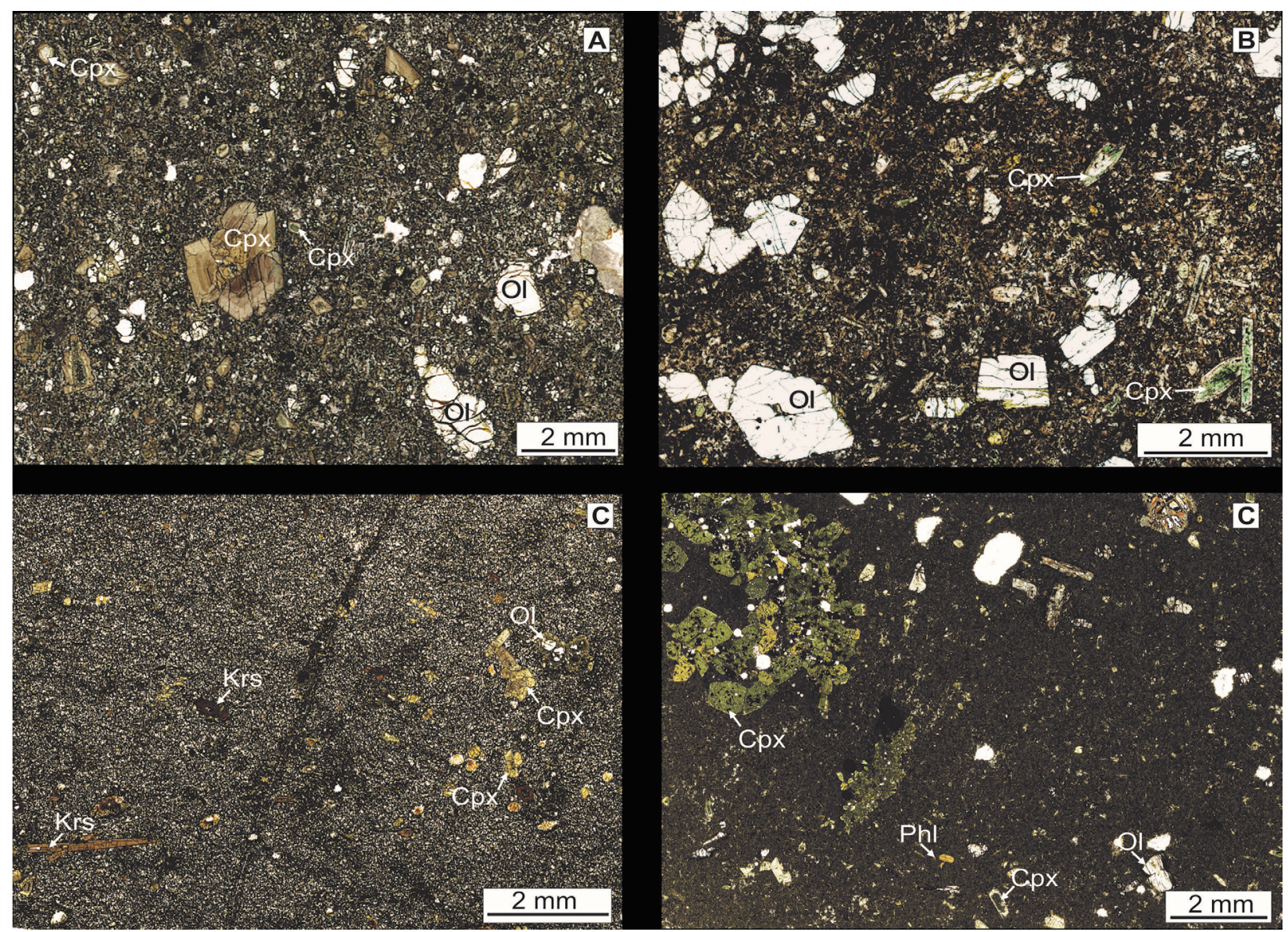

Figure 2. Photomicrographs of the studied samples, showing the porphyritic texture of (A) alkali basalt, (B) olivine alkali basalt, (C) alkaline lamprophyre and (D) phonolitic tephrite. The main macrocrysts of these samples are clinopyroxene (Cpx), olivine (Ol), with subordinate kaersutite (Krs) and phlogopite (Phl), set in a fine-grained groundmass. Plane-polarized transmitted light. 
affected by disequilibrium processes (Fo $>89$ ), core compositions present high $\mathrm{Ni}$ and low Ti contents. In contrast, Type- 2 olivine macrocrysts are subhedral, angular, mostly unzoned but present some variation in $\mathrm{Mg}\left(\mathrm{Fo}_{80-88}\right)$. They represent the main mafic macrocrysts of alkali basalts (Figs. 3C and 3D), and also occur in clusters, defining glomeroporphyritic textures.

\section{Clinopyroxenes}

Common to all described lithotypes, clinopyroxene macrocrysts present a wide petrographic diversity and complex zoning patterns (Fig. 4), with four recognized types: A, B, C, and D; subtypes were also characterized for A- and B-types based on mineral compositional signatures (Tab. 1). Sieve textures are observed in all types, but not in all crystals. Although mainly classified as diopside, pyroxene macrocrysts present important compositional variations, as shown in Figure 5 and Tables A5 and A6 (Suppl. material A).

A-type macrocrysts are colorless, with normal step concentric zoning, and show high and variable $\mathrm{Mg} \#$ values $\left[\mathrm{Mg} \#=100^{*} \mathrm{Mg} /\left(\mathrm{Mg}+\mathrm{Fe}_{\mathrm{T}}\right)\right.$ in mol.; 57-88]. Their compositions define a trend of coupled substitutions of $\mathrm{Si}^{4+}-\mathrm{Al}^{3+}$ in T-site and $\mathrm{Mg}^{2+}-\mathrm{Ti}^{4+} / \mathrm{Fe}^{3+}$ in M1-site (Fig. 5A). Chemically, A-type members can be divided into 5 subtypes: A1, A3, and A5 anhedral and subhedral cores (Figs. 4A, 4E and 4G) and $\mathrm{A} 2$ and $\mathrm{A} 4$ subhedral/euhedral intermediate zones (Figs. 4A-4D). The A1, A3, and A5 core subtypes have different $\mathrm{Mg} \#$ ranges (Tab. 1) and display particular trace element signatures: A1 contains the lowest concentrations of Sr, $\mathrm{Zr}$ (Figs. 5G and 5H), Ga, Y, and rare earth elements (REE; Fig. 6A); A5 presents the highest REE contents among A-types (Fig. 6A); A3 have higher concentrations of Sc, Sr, and $\mathrm{Zr}$ than in $\mathrm{A} 1$ and $\mathrm{A} 5$. The $\mathrm{A} 2$ and $\mathrm{A} 4$ intermediates differ from each other, both by the larger ranges of $\mathrm{Ti}$ and $\mathrm{Mg} \#$ (57-84;
Fig. 5F) in A4 and by the REE concentrations (higher in A4 in most cases; Fig. 6A).

B-type is typically green, characterized by the reverse step concentric zoning and usually occurs as anhedral cores or euhedral intermediate zones (Figs. 4B, 4C, 4E, 4F and 4H). B-type pyroxene is characterized by slightly lower and variable $\mathrm{Mg}^{\#}$ values (41-84) and by coupled substitutions of $\mathrm{Ca}^{2+}$ with $\mathrm{Na}^{+}$ (M2) and $\mathrm{Mg}^{2+}$ with $\mathrm{Al}^{3+}$ or $\mathrm{Fe}^{3+}$ in M1. This type is chemically subdivided into five subtypes: B1, B2, B3, B5 cores, Figs. 4B, 4C, $4 \mathrm{~F}$ and $4 \mathrm{H}$ ) and $\mathrm{B} 4$ intermediate zone mantling (Fig. 4E). $\mathrm{B} 1$ ( $\mathrm{Mg} \#=60-65$; Fig. 5$)$ is characterized by the high concentration of heavy REE and a negative Eu anomaly (Fig. 6B). B2 is compositionally similar to $\mathrm{B} 1$, but with higher $\mathrm{Mg} \#(68-71)$ and lower Si Mn, Sr, Y, Zr and REE concentrations. B3 presents the highest $\mathrm{Mn}, \mathrm{Zn}, \mathrm{Sr}$ and $\mathrm{Zr}$ values among all pyroxenes and lowest $\mathrm{Al}, \mathrm{Fe}^{2+}$ and $\mathrm{Y}$ concentrations among B-type cores, with upward concave REE pattern (Fig. 6B). B5 yields low Sc, with higher $\mathrm{Sr}$ and $\mathrm{Zr}$ than $\mathrm{B} 1$ and B2. Intermediate B4 pyroxenes present the largest compositional gradient of forming cations ( $\mathrm{Si}, \mathrm{Al}, \mathrm{Ti}, \mathrm{Mn}, \mathrm{Na}$ ) and REE distribution pattern similar to that of B3-subtype pyroxene.

C-type refers to pale-pinkish macrocrysts petrographically identified as $\mathrm{Ti}$-augite, corresponding to the main pyroxene in mafic dikes of the Mantiqueira range (except in the phonolitic tephrite) (Figs. 3 and 4). These may occur as isolated euhedral crystals with oscillatory or sector zoning, or in clusters in a glomeroporphyritic texture with inclusions of olivine and opaque minerals or, more commonly, forming the rims of other clinopyroxene macrocrysts. Ti-augite is the prevailing pyroxene variety in the matrix. Being the most common among the pyroxenes, macrocrysts of C-type show a broad $\mathrm{Mg} \#$ range (58-85; Fig. 5). They are often subsilicic and with high $\mathrm{Cr}$ concentrations in some high $\mathrm{Mg} \#$ zones. Silica

Table 1. Summary of petrographic features of the olivine- and pyroxene-types of macrocrysts in the ultrabasic alkaline dykes from the Mantiqueira range. $\mathrm{Mg} \#=100^{*} \mathrm{Mg} /\left(\mathrm{Mg}+\mathrm{Fe}_{\mathrm{T}}\right)$ in apfu $\left(\mathrm{Fe}_{\mathrm{T}}=\mathrm{Fe}^{2+}+\mathrm{Fe}^{3+}\right)$.

\begin{tabular}{|c|c|c|c|c|c|c|c|c|c|}
\hline \multicolumn{3}{|c|}{ Mineral / Type / Subtype } & Zone & $\begin{array}{l}\text { vol. } \\
(\%)\end{array}$ & $\begin{array}{l}\text { Grain size } \\
(\mathbf{m m})\end{array}$ & $\mathbf{M g} \#$ & $\begin{array}{c}\text { Alkali } \\
\text { basalts }\end{array}$ & Lamprophyres & $\begin{array}{c}\text { Phonolitic } \\
\text { tephrite }\end{array}$ \\
\hline \multirow{2}{*}{\multicolumn{2}{|c|}{ Olivine }} & type-1 & $\begin{array}{l}\text { Core, intermediate } \\
\text { zone, rim }\end{array}$ & $1-2$ & $0.2-2.5$ & $71-90$ & $x$ & & \\
\hline & & type-2 & Unzoned & $4-13$ & $0.2-5$ & $80-88$ & $x$ & & \\
\hline \multirow{12}{*}{ Pyroxene } & & A1 & Core & $<1$ & $0.2-1.3$ & $87-88$ & $x$ & & \\
\hline & & $\mathrm{A} 2$ & Intermediate zone & $<1$ & $<0.2$ & $81-84$ & $x$ & & \\
\hline & A (colorless) & A3 & Core & $<1$ & $0.2-0.35$ & $80-84$ & $x$ & $x$ & \\
\hline & & A4 & Intermediate zone & $<<1$ & $<0.05$ & $66-84$ & $x$ & $x$ & $x$ \\
\hline & & A5 & Core & $<<1$ & $<0.5$ & $73-76$ & & $x$ & \\
\hline & \multirow{5}{*}{ B (green) } & $\mathrm{B} 1$ & Core & $<1$ & $0.1-0.4$ & $60-65$ & $x$ & & \\
\hline & & B2 & Core & $<<1$ & $0.25-0.6$ & $68-70$ & $x$ & & $x$ \\
\hline & & B3 & Core & $\sim 2$ & $0.15-1$ & $40-64$ & $x$ & $x$ & \\
\hline & & B4 & Intermediate zone & $<1$ & $<0.2$ & $50-70$ & $x$ & $x$ & \\
\hline & & B5 & Core & $<5$ & $0.05-\sim 1.2$ & $46-68$ & & $x$ & $x$ \\
\hline & $\begin{array}{l}\mathrm{C} \\
\text { (pale-pinkish) }\end{array}$ & $\mathrm{C}$ & $\begin{array}{l}\text { Core, intermediate } \\
\text { zone, rim }\end{array}$ & $1-\sim 4$ & $0.01-1.2$ & $63-85$ & $x$ & $x$ & $x$ \\
\hline & $\mathrm{D}$ (colorless) & $\mathrm{D}$ & Core & $<1$ & 0.15 & 61 & $x$ & & \\
\hline
\end{tabular}


concentration decreases proportionally with $\mathrm{Mg}$, while $\mathrm{Al}$ and Ti increase (Fig. 5). The rims of these macrocrysts are enriched in $\mathrm{Ti}, \mathrm{Al}, \mathrm{Sr}, \mathrm{Y}, \mathrm{Zr}, \mathrm{Nb}$, and REE. The concentration of light rare earth elements (LREE) in this type is the highest among pyroxenes, with enrichments up to 600 times the chondritic reservoir (Fig. 6C).
D-type macrocrysts are restricted to a sample of alkali basalt, occurring as anhedral cores that are distinguished by their grey tones (Fig. 4D). D-type pyroxenes are classified as enstatite $\left(\mathrm{Mg}^{\#}=61\right.$; Fig. 4D). Their $\mathrm{Co}, \mathrm{Ni}$, and $\mathrm{Zn}$ concentrations are among the highest of all, while their light and intermediate REE and Y values are among the lowest ones (Fig. 6C).

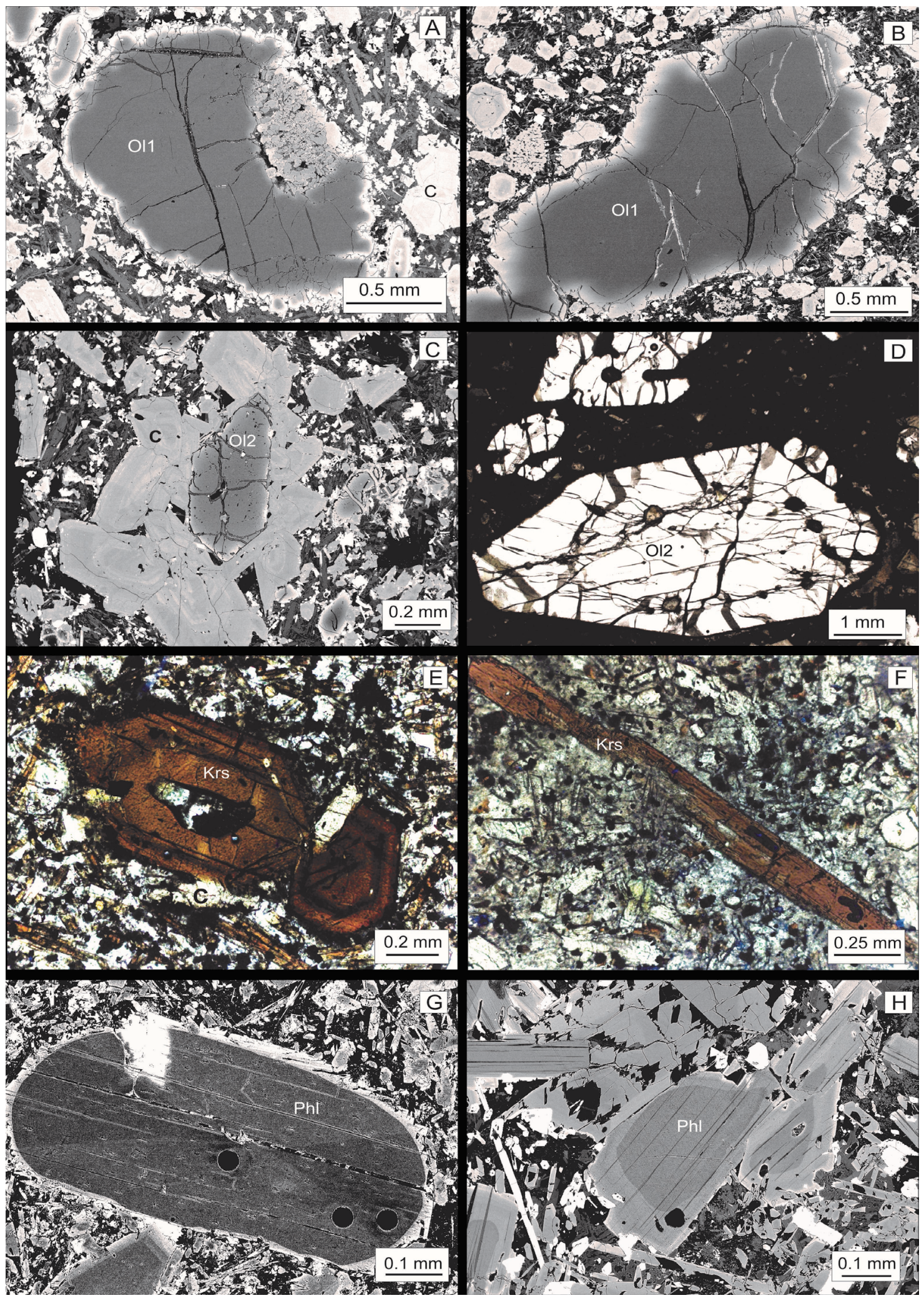

Figure 3. Petrographic features of mafic macrocrysts of the ultrabasic alkaline dikes from the Mantiqueira mountain range. Type 1 olivines are found in (A) and (B), whereas type 2 olivines are found in (C) and (D). Kaersutite macrocrysts are found in (E) and (F), whereas phlogopite macrocrysts are found in $(\mathrm{G})$ and $(\mathrm{H})$. The dark roles in $(\mathrm{G})$ and $(\mathrm{H})$ are related to laser ablation spots. More details are offered in the main text. A-C and G-H are back-scattered electron images; D-E and F, plane-polarized transmitted light. 
Given the clinopyroxene complexity, the relationships between the different types and subtypes are summarized in Figure 7. A1-, B1-, B2- and D-cores are mantled by A2-intermediate, which is mantled by C-type. A5- and B5-cores are mantled by A4-intermediates, which is mantled by C-type. A3-and B3-cores are mantled by B4-intermediate, which is mantled by C-type.

\section{Amphiboles}

Kaersutite is rare in alkali basalts, but forms the main macrocrystic phase of lamprophyres from the Mantiqueira range (3-6\% by volume) (Figs. $3 \mathrm{E}$ and $3 \mathrm{~F}$ ). They occur in a variety of habits (e.g., euhedral tabular, anhedral rip, skeletal) and also occur as clusters, defining glomeroporphyritic

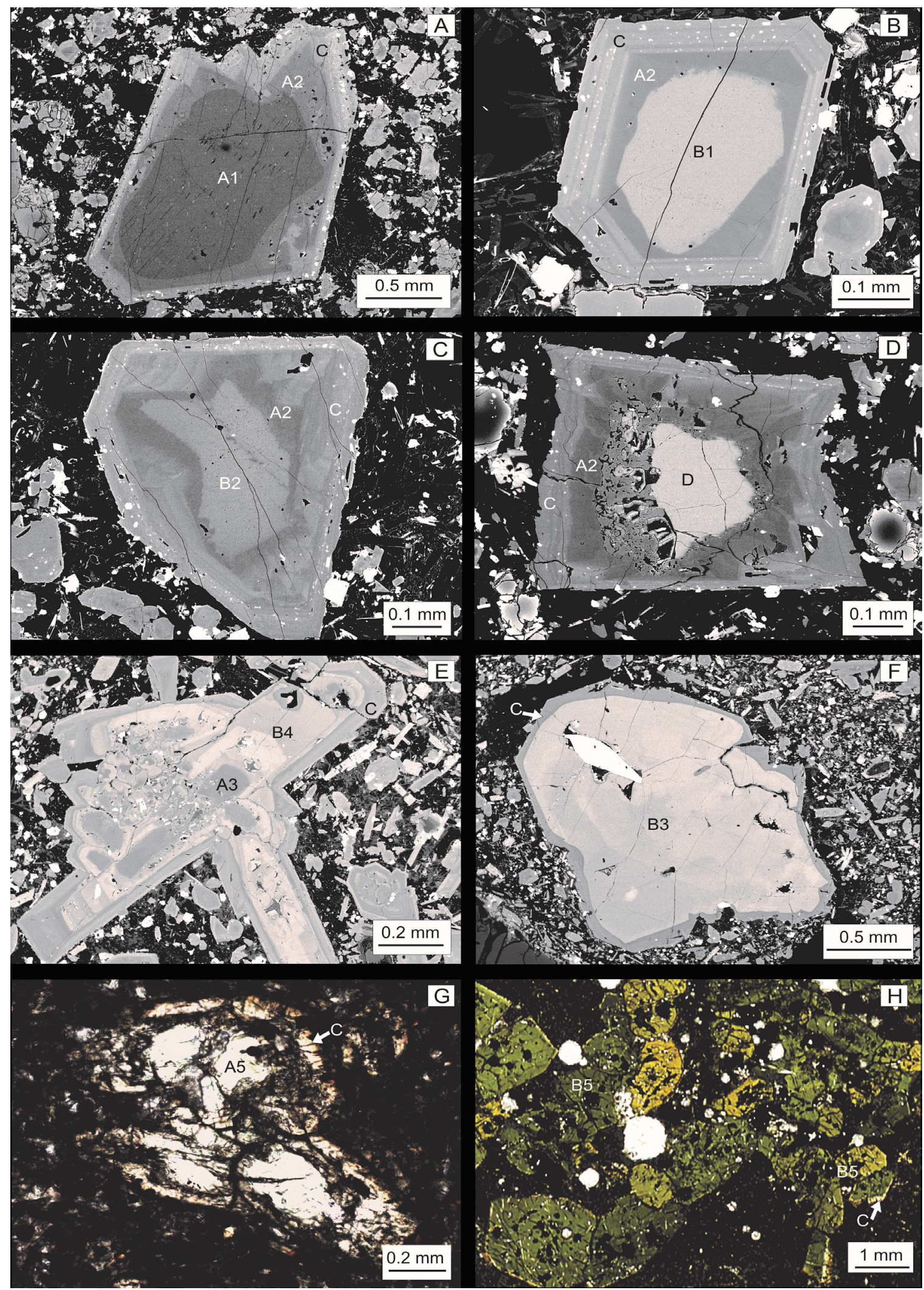

Figure 4. Petrographic details of pyroxene macrocryst populations in the ultrabasic alkaline dikes from the Mantiqueira range. A1-A5, B1-B5, $\mathrm{C}$, and $\mathrm{D}$ refer to the different types and subtypes of pyroxene macrocrysts identified in this work (see the main text and table 1 for further details). (A-F) Back-scattered electron images; (G-H) plane-polarized transmitted light. 
textures. Sector or concentric oscillatory zoning may be present. Chemically, the amphiboles are mainly classified as kaersutite, with minor pargasite and $\mathrm{Mg}$-hastingsite $(\mathrm{Ti}<0.5 \mathrm{apfu})$ (Tabs. A7 and A8 - Suppl. Material A). Euhedral kaersutite macrocrysts described in the monchiquite (Fig. 3E) have higher $\mathrm{Mg}^{\#}$, while kaersutite and pargasite from alkali basalt and camptonite (Fig. 3F) are anhedral with lower $\mathrm{Mg}^{\#}$ and Si. Amphiboles are enriched in LREE relative to heavy rare earth elements (HREE) (Fig. 8), with monchiquite presenting REE contents $\left(\sum R E E=248-319\right)$ lower than those of the alkali basalt $\left(\sum \mathrm{REE}=424-509\right)$ and camptonite $(\Sigma \mathrm{REE}=572-625)$.
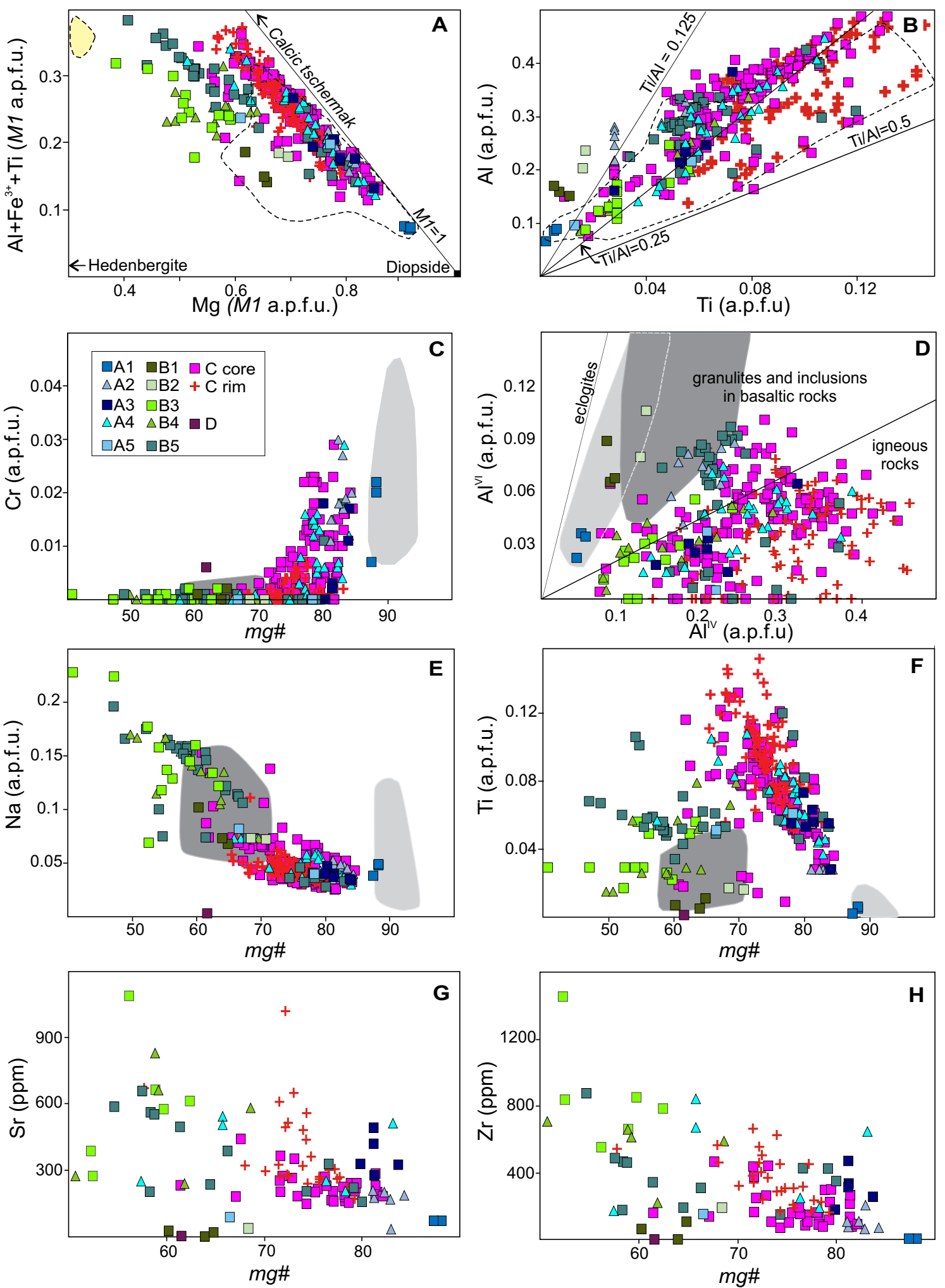

Figure 5. Compositional variation of clinopyroxenes in the ultrabasic alkaline dikes from the Mantiqueira range. Dashed-contour and yellow fields in A-B are related to clinopyroxenes of mafic and felsic rocks, respectively, from the nearby Ponte Nova alkaline massif. Light- and dark-gray fields in C-F diagrams are related to mantle-derived and lower crust-derived xenocrysts, respectively, following Jankovics et al. (2016). General fields for eclogites, granulites and inclusions in basaltic rocks and igneous rocks in D diagram from Aoki and Kushiro (1968). $\mathrm{Mg} \#=\left[100^{*} \mathrm{Mg} /\left(\mathrm{Mg}+\mathrm{Fe}_{\mathrm{T}}\right)\right]$. 


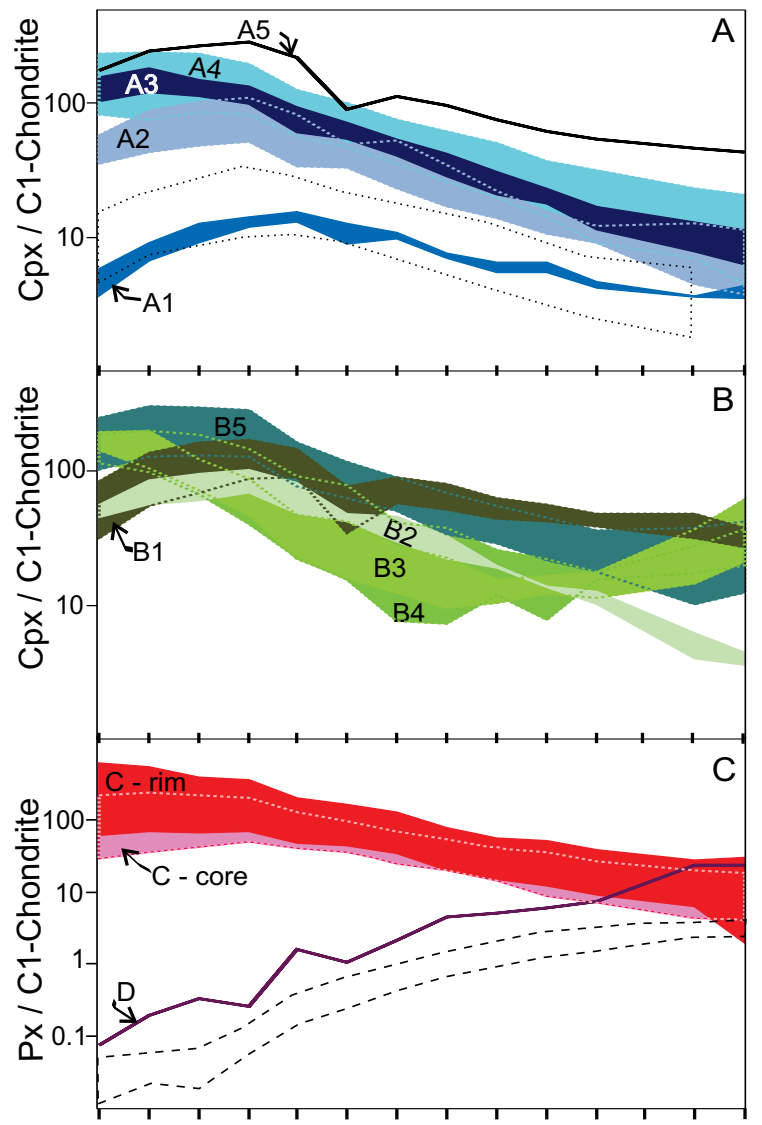

La Ce Pr NdSm Eu Gd Tb Dy Ho Er Tm Yb Lu

Figure 6. C1-chondrite-normalized distribution patterns of pyroxene populations in the ultrabasic alkaline dikes from the Mantiqueira Range. Each type is identified in the respective field. See the main text for more information. Dotted-contour field in $\mathrm{A}$ and dashed-contour field in $\mathrm{D}$ are related to garnet lherzolite clinopyroxenes and orthopyroxenes, respectively, following Lesnov (2010). C1-chondrite composition from McDonough and Sun (1995).

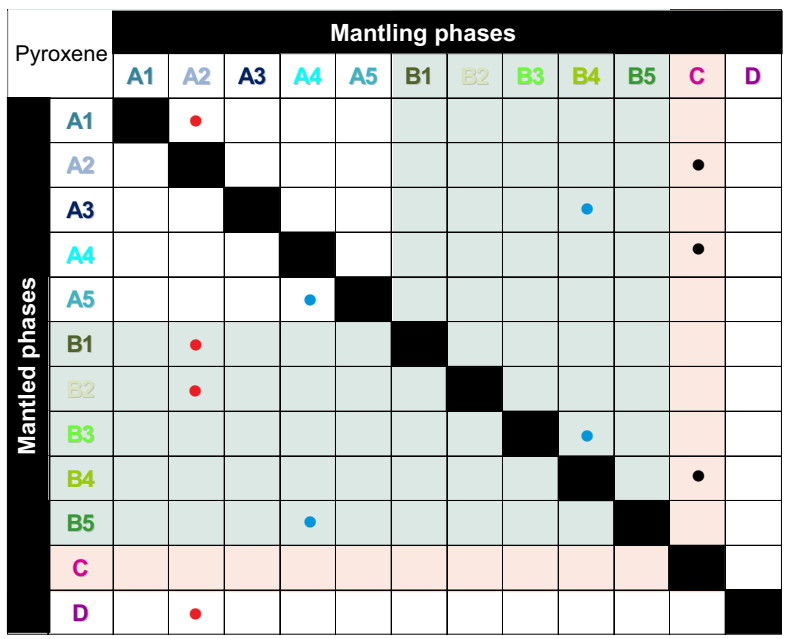

Figure 7. Clinopyroxene crystal stratigraphy. Each petrographic population is represented by differences in background colors of the diagram: A-subtypes are colorless, B-subtypes are green, C-type is the pale-pinkish to pale brown Ti-augite, and D-type is colorless orthopyroxene. Red bullets are xenocrystic mantled phases, blue bullets are antecrystic mantle phases, and black bullets are phenocryst mantling phases.

\section{Phlogopite}

Although common in the matrix of lamprophyres and phonolitic tephrite, phlogopite macrocrysts were described in only two samples (Figs. $3 \mathrm{G}$ and $3 \mathrm{H}$ ). In camptonite, these macrocrysts are anhedral, have concentric zoning and are associated with kaersutite, anhedral pyroxene and olivine pseudomorphs. In the phonolitic tephrite sample, however, a single isolated phlogopite macrocryst is present with rounded anhedral habit, and sector zoning. All crystals analyzed are classified as titanian phlogopites, with very restricted $\mathrm{Mg} \#\left[100^{*} \mathrm{Mg} /\right.$ $\left.\left(\mathrm{Mg}+\mathrm{Fe}^{2+}\right): 72-80\right]$ values (Tabs. A9 and A10 - Suppl. Material A). They present high Ba (4,908-1,4761 ppm), Sr (3,23-761 ppm), and Rb (253-407 ppm) contents coupled with low Y (0.16-7.09 $\mathrm{ppm})$ values.

\section{Whole-rock geochemistry}

Whole-rock geochemical analysis (Suppl. Material B; cf. Azzone et al. 2018) indicate that the studied dikes are ultrabasic $\left(<45 \mathrm{wt} \% \mathrm{SiO}_{2}\right)$, have alkaline affinity (Irvine and Baragar 1971) with normative nepheline and olivine, and present high $\mathrm{MgO}$ (5.1 wt\%) and $\mathrm{TiO}_{2}$ (3.9-wt\%). While some alkali basalt and lamprophyres present potassic affinity (which prevails in the Serra do Mar Alkaline Province), others are of sodic affinity and belong to a strongly silica-undersaturated series (Azzone et al.2018). The phonolitic tephrite dike shows ultrapotassic affinity $\left(\mathrm{K}_{2} \mathrm{O}>3 \mathrm{wt} \%, \mathrm{MgO}>3 \mathrm{wt} \%\right.$, and $\mathrm{K}_{2} \mathrm{O} / \mathrm{Na}_{2} \mathrm{O}>2 \mathrm{wt} \%$; Foley et al. 1987); quite unusual in the province (Garda 1995, Valente 1997, Marins 2012, Rosa 2017). Chondrite-normalized REE patterns are sub-parallel, with an abundance of light over heavy elements. REE concentrations are higher in the ultrapotassic phonolitic tephrite, followed by lamprophyres and alkali basalts.

\section{DISCUSSION}

\section{Crystal-liquid equilibrium}

The diversity and distribution of macrocryst populations (types and subtypes) in mafic dikes of the Mantiqueira region are thought to derive from distinct magma-types and/or different

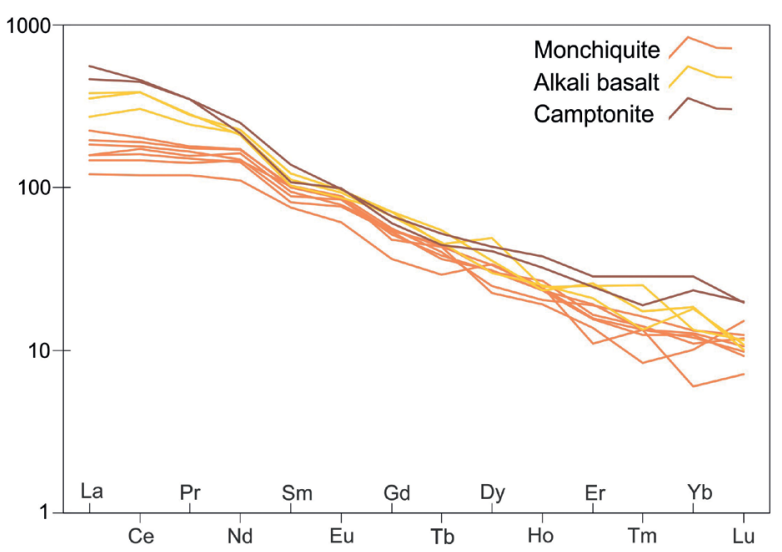

Figure 8. C1-chondrite-normalized signatures of amphiboles in the ultrabasic alkaline dikes from the Mantiqueira range. C1-chondrite composition from McDonough and Sun (1995). 
evolution processes. In order to understand the origin of each type and subtype, their equilibrium relationships with the host magmatic melt must be established. Subsequently, petrological studies will trace magmatic processes responsible for their genesis.

The mineral-melt equilibrium relationship can be geochemically modeled from crystals and host liquid compositions (Putirka 2008). The matrix composition may be considered the best estimate of the magmatic melt for porphyritic subvolcanic rocks. Recent studies evaluate that the bulk rock composition of a porphyritic subvolcanic rock corresponds to the sum of the high crystal cargo (some of them recycled and in disequilibrium with the magmatic melt) and the magmatic liquid represented by the fine-grained to aphanitic matrix (Ubide et al. 2012, Menezes et al. 2015). In this way, mass balance calculations were performed in order to exclude the influence of the macrocrysts on the whole-rock geochemistry, according to the Equation 1 of Ubide et al. (2012):

$X_{M}^{i}=\frac{X_{R}^{i}-\sum\left(X_{C}^{i} * p\right)}{1-\sum p}$

In which:

$X=$ the concentration of the chemical element $(i)$ in the whole$\operatorname{rock}(R)$, in its matrix $(M)$, and in a crystal $(C)$, with $p$ representing the modal value of the mineral phase.

A modal discount of 0.1 was applied to Ti-augite and kaersutite once they present features suggestive of mineral-melt equilibrium (i.e., glomeroporphyritic texture, euhedral habit and normal zoning). Those phases would therefore correspond to phenocrysts and their volume shall not be subtracted from the whole-rock geochemistry. For the other mineral species present, the average composition of each type of macrocryst was calculated (Suppl. Material C).

Once the influence of macrocrysts was discounted, the representative composition of the host liquid could be established (Suppl. Material C). The calculated melts presented basanitic and tephritic compositions, with $\mathrm{Mg} \#[\mathrm{MgO} /(\mathrm{MgO}$ $+\mathrm{FeO}$ ), mol. proportions] ranging from 42 to 68 . Partition between $\mathrm{Fe}_{2} \mathrm{O}_{3}$ and $\mathrm{FeO}$ of the calculated melt was obtained using the MELTS algorithm (Asimow and Ghiorso 1998), assuming a quartz-fayalite-magnetite (QFM) buffer for each sample. Mineralogical composition and empirical tests using $1,100-1,200^{\circ} \mathrm{C}$ and $0.5-1 \mathrm{kbar}$ were considered in the selection of buffers. Using loss on ignition (LOI) as reference, the amount of volatiles corresponds to $1.5-2.6 \mathrm{wt}$. $\mathrm{H}_{2} \mathrm{O}$ and $0.5-1.1$ wt. $\% \mathrm{CO}_{2}$.

The usual method for estimating the chemical composition of crystals in equilibrium with their host liquid consists in the application of cation-exchange equilibrium constants. In mafic igneous rocks, $\mathrm{FeO}$ and $\mathrm{MgO}$ exchanges between the magmatic liquid and ferromagnesian minerals are experimentally quantified and applied to geochemical models of crystal-liquid equilibrium (Putirka 2008 and references therein) as (Eq. 2):

$\mathrm{MgO}_{\text {crystal }}+\mathrm{FeO}_{\text {liquid }} \leftrightarrow \mathrm{MgO}_{\text {liquid }}+\mathrm{FeO}_{\text {crystal }}$
$\mathrm{Kd}(\mathrm{Fe}-\mathrm{Mg})^{\mathrm{C}-\mathrm{L}}=\frac{X_{\mathrm{Fe}}{ }^{\mathrm{C}} X_{\mathrm{Mg}}{ }^{\mathrm{L}}}{X_{\mathrm{Mg}}{ }^{\mathrm{C}} \mathrm{X}_{\mathrm{Fe}}{ }^{\mathrm{L}}}$

In which:

$\mathrm{X}=$ the composition of $\mathrm{Fe}^{2+}$ and $\mathrm{Mg}^{2+}$ in $\operatorname{crystal}(C)$ or liquid $(L)$; $\mathrm{Kd}(\mathrm{Fe}-\mathrm{Mg})^{\mathrm{C}-\mathrm{L}}=$ the diffusion exchange constant between both forms.

Thus, a crystalline composition in equilibrium with the magmatic liquid can be calculated from the liquid composition and the partition coefficient. By indicating a Kd error range, a compositional interval that closely represents a state of chemical equilibrium is obtained.

Different Fe-Mg exchange constants between the minerals of interest and alkaline mafic liquids were compiled from the literature: $K d_{\mathrm{Fe}-\mathrm{Mg}}^{o / \mathrm{liq}}=0.312 \pm 0.03$ (Azzone et al. 2013) for olivine, $K d_{\mathrm{Fe}-M g}^{c p / l i q}=0.26 \pm 0.03$ (Akinin et al. 2005) for clinopyroxene, $K d_{\mathrm{Fe}-M g}^{\text {amp } / \text { liq }}=0.38 \pm 0.05$ for amphibole, and $K d_{\mathrm{Fe}-M g}^{\mathrm{phl} / \mathrm{Mg}}=0.34 \pm 0.05$ for phlogopite (LaTourrette et al. 1995).

Equilibrium relations are shown in binary dispersion diagrams of crystal versus liquid Mg\# (Figs. 9 and 10). Close-to-equilibrium compositional intervals (dashed lines) discriminate phenocrysts from antecrysts and/or xenocrysts. Crystalline compositions in chemical disequilibrium with the host liquid were observed in all mafic minerals. Xenocrysts were distinguished from antecrysts by the integration of features such as habit, modal content, zoning style, resorption, re-equilibrium, and crystallization textures and the composition of major, minor and trace elements in mineral species. Crystalline compositions in equilibrium with the magmatic liquid are representative of C-type clinopyroxenes (at least part of these) (Fig. 9) and amphibole from the most evolved alkali basalts (Fig. 10B), which compose the matrix of dikes. Therefore, the genetic differences among macrocrystic populations found in the dikes from the Mantiqueira range are discussed below.

\section{Xenocrysts}

Based on textural controls, compositional crystal-liquid disequilibrium relations (Figs. 9 and 10), and trace-element signatures, different populations of xenocrysts were assigned for the dikes of the Mantiqueira range: Type-1 olivine, A1-, B1- and B2-subtypes and D-type of pyroxenes. All these types and subtypes are representative of cores of macrocrysts. Type-1 olivine, chromium diopside from A1-subtype, enstatite (D-type), olivine (type-1), chromium diopside (A1-subtype) and green-core B1-subtype are found exclusively in the alkali basalt dikes, whereas the B2-subtype is found in alkali basalts and phonolitic tephrite dike. Type-1 olivine and A1-subtype chromium diopside and D-type enstatite can be assigned to a mantle origin, while the B1- and B2-subtypes can be related to lower crust levels.

Some type- 1 olivine cores yield concentrations of $\mathrm{Ca}$ $(<700 \mathrm{ppm})$ and $\mathrm{Ti}(<70 \mathrm{ppm})$ that resemble mantle xenocrysts, as well as high Fo ( $>90)$, following the criteria of Foley et al. (2013). Type-1 olivine crystals have rounded anhedral habit and with embayment texture, indicating that they were in 
disequilibrium with the host magma and confirming a xenocrystic origin. Chemically, the compositional overlapping of some portions of type-1 olivine crystals with the chemical equilibrium interval of alkali basalt and lamprophyre matrices (Fig. 10A) can be assigned to Fe-Mg diffusive exchanges, probably related to sub-solidus diffusive processes.

A1-type clinopyroxene cores in alkali basalt show the highest $\mathrm{Mg} \#(87-88)$ and lowest $\mathrm{Ti} / \mathrm{Al}$ ratios $(<0.125)$ of the cases studied, indicating high crystallization pressure (Thy 1991). Such values are also observed in chromium-bearing diopside crystals from mantle xenoliths in alkali basalts

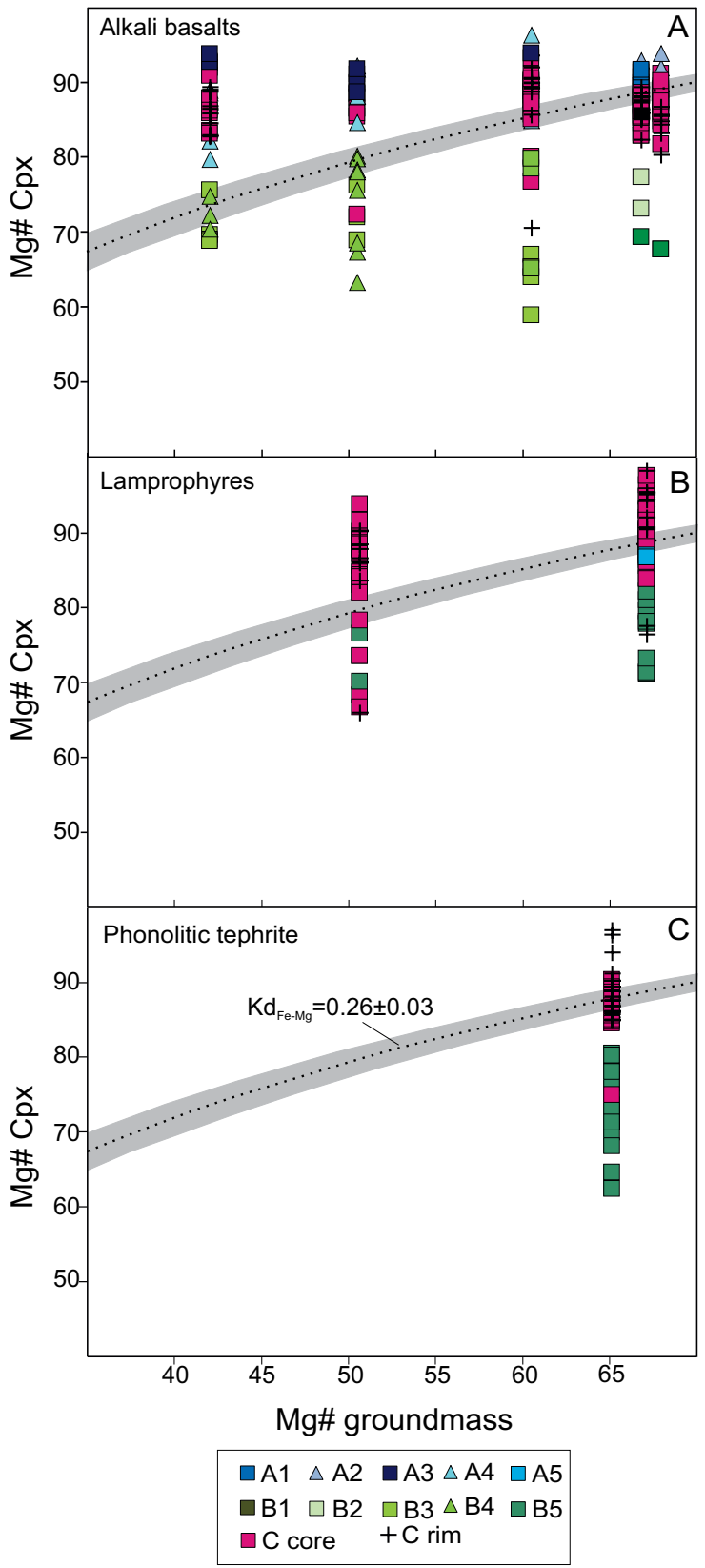

Figure 9. Clinopyroxene-melt equilibrium diagrams for (A) alkali basalts, (B) alkaline lamprophyres, and (C) phonolitic tephrite from the Mantiqueira range. The curves represent the range in which mineral and melt compositions are in equilibrium based on ironmagnesium exchange coefficients (Akinin et al. 2005). The Mg\# $\left[\mathrm{Mg} /\left(\mathrm{Mg}+\mathrm{Fe}_{\mathrm{T}}\right)\right]$ concentration of the melt was calculated from whole-rock compositions after discounting the macrocryst cargo influence, representing groundmass melts of each rock-type.
(Pilet et al. 2002, Jankovics et al. 2016). A1-type cores also have more primitive compositions than those expected for equilibrium crystallization with the hosting liquid (Fig. 9). The $\mathrm{Cr},{ }^{\mathrm{VI}} \mathrm{Al},{ }^{\mathrm{IV}} \mathrm{Al} \mathrm{Na}, \mathrm{Ti}$, and $\mathrm{Mg} \#$ values of these macrocrysts (Figs. 5C-5F) widely overlap those observed in clinopyroxenes from the lithospheric mantle (Jankovics et al. 2013 and references therein). The $\mathrm{Al}+\mathrm{Cr}-\mathrm{Na}-\mathrm{K}<0.05$ (Read et al. 2004) and $[\mathrm{Ca} /(\mathrm{Ca}+\mathrm{Mg}+\mathrm{Fe})]<0.46($ Grütter 2009) criteria indicate an origin of A1-subtype xenocrysts from garnet-bearing mantle rocks. The low concentration of $\Sigma \mathrm{REE}$ (18.8-23.5 ppm) and the flat chondrite-normalized signature are also similar to
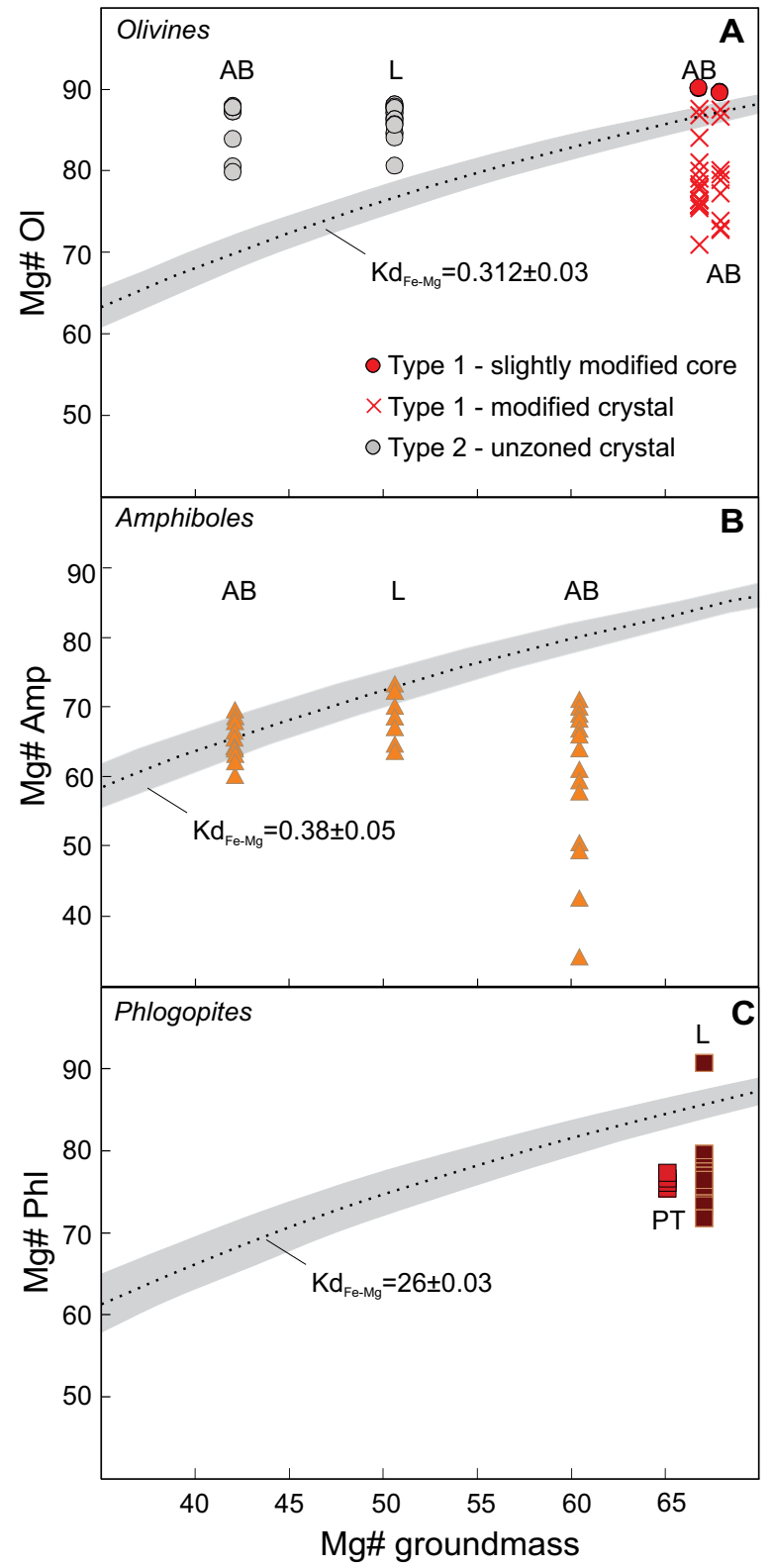

AB: alkali basalts; L: lamprophyres; PT: phonolitic tephrite.

Figure 10. Mineral-melt equilibrium diagrams for (A) olivines, (B) amphiboles, and (C) phlogopites from the ultrabasic alkaline dikes from Mantiqueira range. The curves represent the range in which mineral and melt compositions are in equilibrium based on ironmagnesium exchange coefficients (Azzone et al. 2013, LaTourrette et al. 1995). The $\mathrm{Mg} \#\left[100^{*}-\mathrm{Mg} /\left(\mathrm{Mg}+\mathrm{Fe}^{2+}\right)\right]$ concentration of the melt was calculated from whole-rock compositions after discounting the macrocryst cargo influence, representing groundmass melts of each rock-type. $\mathrm{Mg}^{\#}{ }_{\text {mineral }}=\left[100^{*} \mathrm{Mg} /\left(\mathrm{Mg}+\mathrm{Fe}^{2+}\right)\right]$. 
those of clinopyroxenes from garnet lherzolite and garnet-spinel lherzolite facies (Lesnov 2010; Fig. 6A). This occurrence corroborates the proposition of garnet lherzolite sources for the mafic alkaline occurrences over the region (Azzone et al.2018).

D-type enstatite cores are also considered xenocrysts. The saturation in silica, re-equilibrium and recrystallization features of enstatite (D-type) cores corroborate their unlikely genesis from alkaline magmas. REE distribution patterns normalized by the C1-chondrite are similar to those of lherzolite orthopyroxenes from the Lizard complex, Cornwall (Lesnov 2010; Fig. 6C), although somewhat more REE-enriched than those. These characteristics point to an origin outside the magmatic system, possibly incorporated from mantle or lower crustal rocks.

B1- and B2-subtype cores are also considered xenocrysts. They are enclosed by the same groundmass as the other xenocryst populations, with which they share the low $\mathrm{Ti} / \mathrm{Al}$ ratio (<0.125), like to A1-subtype. They have more evolved compositions than those expected for equilibrium crystallization with the hosting liquid (Fig. 9). Moreover, B1 and B2 cores show ${ }^{\mathrm{VI}} \mathrm{Al} /{ }^{\mathrm{IV}} \mathrm{Al}$ ratios (0.64-1.08) distinctly higher than other B-subtypes (up to 0.49 ), closer to those of A1 xenocrysts (0.52-0.74), thus indicating deeper crystallization levels. B1 and $\mathrm{B} 2$ show $\mathrm{Cr}, \mathrm{Na}, \mathrm{Ti}, \mathrm{Mg}^{\mathrm{V}}$, ${ }^{\mathrm{VI}} \mathrm{Al}$, and ${ }^{\mathrm{IV}} \mathrm{Al}$ values with good correspondence with clinopyroxenes from lower crustal mafic granulite xenoliths (Figs. 5C-5F). Besides, their compositions overlap those of the green cores described by Jankovics et al. (2013), interpreted as xenocrysts derived from lower crustal levels (mafic granulites).

In the Serra do Mar Alkaline Province, just xenocrysts and xenoliths of spinel-lherzolite facies had been described in one alkaline lamprophyric dike on the northern coast of São Paulo (Almeida 2009). Our study represents the first report of mantle and lower crust xenocrysts in the Mantiqueira range, also the first recognition of mantle xenocrysts from garnet-bearing levels on the Province.

\section{Antecrysts}

The antecrysts mainly consist of macrocryst zones that are cogenetic to the magmatic system but formed by open-system magmatic processes. Based on chemical (Figs. 9 and 10) and textural disequilibrium relationships with the host magmatic melt, a main antecryst assemblage is designed for the studied dikes: A3- A5-, B3-, B5-cores subtypes and some C-types clinopyroxenes, Type-2 olivine, amphibole, and phlogopite.

A3- and A5-cores (Mg\#: 78-84) are compositionally similar to the clinopyroxenes of the more primitive cumulatic rocks from the nearby mafic-ultramafic Ponte Nova massif (Figs. 5A and 5B; Azzone 2008, Azzone et al.2016), while the chemical compositions of B3- and B5-cores (Mg\#: 47-68) trend toward the clinopyroxenes from Ponte Nova evolved felsic rocks (Fig. 5A; Azzone 2008). Core-subtypes of both groups occur in the same samples and they do not present textural (rounded, corroded cores) and chemical (Fig. 9) equilibrium with the host matrix. A3- and A5-subtypes have more primitive compositions, whereas B3- and B5-cores present more evolved ones than those expected to be crystallized in equilibrium with host groundmass (Fig. 9), allowing their interpretation as antecrysts.
In most cases, these antecrystic cores are enclosed by intermediate zones of a different subtype (A4 and B4) through normal or reverse step zoning. A2-intermediate zones seem to be restricted to the mantling of xenocrysts. These intermediate zones could be generated by crystallization (mantling) or intracrystalline diffusion, considering that $\mathrm{C}$-type phenocryst mantle all macrocrysts. For most cases, A2-, A4, and B4 can be considered antecrysts, due to its chemical disequilibrium with the host liquid (Fig. 9). Some zones of B4-subtype, however, present compositions in equilibrium with the more evolved compositions of alkali basalts, being those classified as phenocrysts. Then, antecryst cores crystallized from different alkaline magmas (with more primitive compositions for $\mathrm{A}$ and more evolved for B) are found on the same samples, with A-type cores enclosed by B-type intermediate zones or viceversa (in both cases in disequilibrium with the host matrix), suggesting magma mixing processes.

Type-2 olivine as well as part of C-type clinopyroxexes are not in chemical equilibrium with evolved alkali basalts and lamprophyres. Clusters of olivines and C-type pyroxenes are found in these rocks (Fig. 3C), suggesting concomitant crystallization. Thus, they can be referred to as antecrysts, although most of C-type overgrowths, individual crystals, and rims have another origin, as discussed in item 5.4.

Kaersutite and pargasite macrocrysts are sporadic in the most primitive alkali basalts and they are not in chemical equilibrium with the matrix, thus being considered antecrysts (Fig. 10B). In phonolitic tephrite, macrocrysts of B5-subtype clinopyroxene and phlogopite do not present chemical equilibrium with the host magmatic liquid (both are more evolved than the expected equilibrium compositions), being therefore interpreted as antecrysts (Figs. 9C and 10C). Phlogopite in lamprophyres also present more evolved compositions than those in equilibrium with the liquid and are considered antecrysts too (Fig. 10C).

\section{Phenocrysts}

The main phenocryst assemblage of the studied dikes is represented by Ti-augite (as final overgrowths on antecrysts) and kaersutite (as euhedral to subhedral macrocrysts composing the dike matrix). They both mostly present compositions close to the chemical equilibrium with the matrix of the studied dikes, indicating their phenocrystic character.

All C-type crystals are widespread in the different mafic alkaline dikes, presenting similar petrographic character and chemical trends, with $\mathrm{Ti} / \mathrm{Al}$ ratios greater than 0.25 . Such characteristic suggests a shallower crystallization environment when compared to other clinopyroxene antecrysts and xenocrysts (Thy 1991). The association of C-type antecrysts with olivine antecrysts in crystalline aggregates (glomeroporphyritic texture) leads to the hypothesis of these having occupied the same magmatic chamber previously to the crystallization of C-type phenocrysts in the magmatic system.

Kaersutite is the main mafic phase in the monchiquite and in the most evolved alkali basalts. These are euhedral and subhedral crystals and are in chemical equilibrium with the host matrix (Fig. 10C), being classified as phenocrysts. Kaersutite phenocrysts 
occur in the association of C-type clinopyroxene phenocrysts, and in the same samples that present clusters of C-type and type- 2 olivine antecrysts. It is suggested that the crystallization of the titaniferous amphiboles is consistent with a same shallow magmatic level of formation, albeit latter than the formation olivine and C-type antecrysts, and phenocrysts.

\section{Mixing of alkaline magmas and antecryst populations}

According to complex plumbing system models (Marsh 2006, Jerram and Martin 2008, Ubide et al. 2014a, 2014b, Cashman et al. 2017, Burchardt 2018, Jerram and Bryan 2018), magmas generated at different depths in the lithosphere would ascent, be stored and consolidated through an internally connected magmatic system composed of a channel network similar to pipelines. Such connections promote interactions among different magmas and host rocks, allowing cogenetic or captured crystals (antecrysts or xenocrysts, respectively) to be efficiently recycled during magma ascent through the lithosphere. Those interactions are recorded by complex zoning patterns and by a diversity of crystal types and mineral populations in subvolcanic and volcanic rocks, as in alkaline ultrabasic dikes of western Mantiqueira range. Mixing and mingling processes are expected to take place in such complex systems.

Batches of distinct magmas with contrasting compositions and already carrying a certain amount of early formed or transported crystals may interact along the plumbing system. As a result, a hybrid magmatic liquid in chemical disequilibrium with the host crystals (antecrysts or xenocrysts) is generated (e.g., Ubide et al. 2014a, Jankovicks et al. 2016). Xenocrysts and antecrysts can be considered the main pieces of evidence of magma evolution stages prior to the arrival at final consolidation sites (Ubide et al. 2014a). In the alkaline ultrabasic dikes of western Mantiqueira range, populations of clinopyroxene antecrysts suggest the important role of magma mixing processes during rock formation. The compositional differences among clinopyroxene antecryst populations allow them to be understood as minerals crystallized from different alkaline magmas, as mafic and felsic poles are identified. So, A-type zones present compositional trends related to alkaline mafic-ultramafic magmas identified in the region (e.g., basanites and tephrites; Brotzu et al. 2005, Azzone et al.2018). On the other hand, B-type macrocrysts show substitution trends compatible with clinopyroxenes of felsic alkaline magmas (e.g., phonolites and trachyte; Brotzu et al. 1997, Melluso et al. 2017). Compatible with the scenario of interaction of mafic and felsic alkaline magmas, A-type cores are surrounded by B-type intermediate zones, while B-type cores are surrounded by A-type compositions (Figs. 4B, 4C and 4E). Such features suggest that both magmas (each responsible for the crystallization of a different group of antecrysts) interacted early along the plumbing system. A differentiation stage subsequent to the mafic-felsic magmas interaction is indicated by the late overgrowth of C-type rims, presumably crystallized in a shallower environment with greater melt homogeneity (Fig. 4).
Mixing between partially crystallized magmas of different chemical compositions would lead to the generation of a hybrid liquid. As such, its composition would be intermediate between the mixture poles (or end-members), with an inherited population of antecrysts from each component. In order to test the hybrid chemical composition of the host liquid, partition coefficients of clinopyroxene/mafic alkaline magmas and of clinopyroxene/felsic alkaline magmas were compiled from the literature for different trace elements. The concentrations of a trace element in an early magmatic liquid (and, consequently, the composition of the liquid itself) can be estimated from the concentrations of the same elements in antecrysts and their partition coefficients between antecrysts and host liquids (Eq. 3):

$K d_{i}^{C / L}=\frac{X i^{C}}{X i^{L}}$

In which:

$\mathrm{X}=$ the concentration of an element (i) in the antecryst (C) and in the liquid (L).

Liquid compositions were calculated for A- and B-type antecrysts, considering the trace element concentrations presented in supplementary material A (Tab. A6). La, Nb, Zr, and $\mathrm{Y}$ were the incompatible trace elements chosen for calculation. The ratios among these elements help minimize any influence by fractional crystallization processes. The partition coefficients chosen for each type of antecryst are in Table D1 (Suppl. Material D). Additionally, the magmatic liquid in equilibrium with $\mathrm{C}$-type phenocrysts was calculated from a partition coefficient previously established for the dikes of the region (Ambrosio and Azzone 2018).

The extreme magmatic liquid compositions from which the different subtypes of antecrysts crystallized were used as poles (A3, A5, B5). Simple mixture curves of two components were plotted on binary diagrams (Fig. 11).

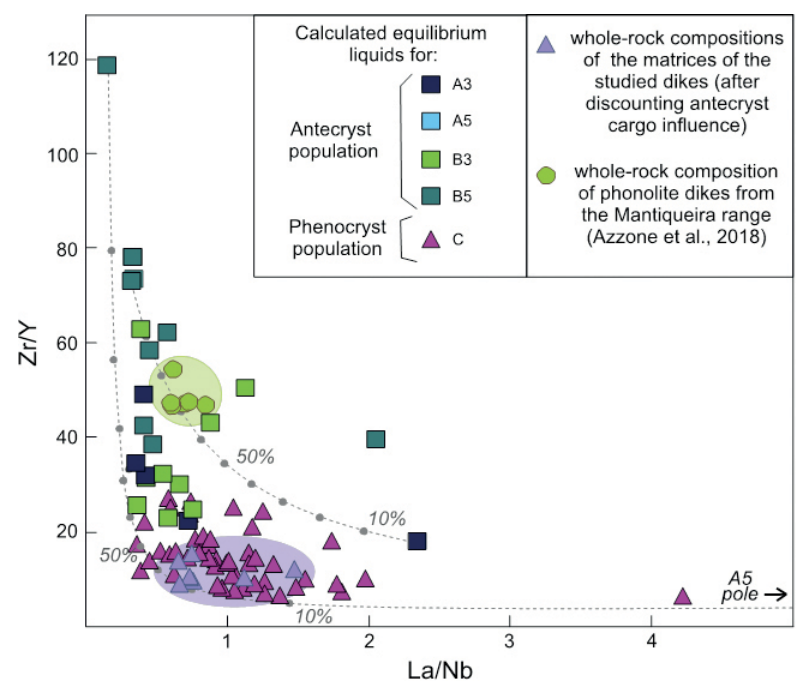

Figure 11. Diagram of $\mathrm{La} / \mathrm{Nb}$ vs $\mathrm{Zr} / \mathrm{Y}$ for the calculated liquids in equilibrium with each clinopyroxene antecryst type found in the alkaline ultrabasic dikes from the Mantiqueira range. Binary mixing-model curves are also shown to indicate the interaction between mafic and felsic magma composition during the complex plumbing system. 
Compositions were modeled under PETROMODELER software (Ersoy 2013) according to the mixing equation of Powell (1984) as (Eq. 4):

$C_{m}=X\left(C_{a}-C_{b}\right)+C_{b}$

In which:

$\mathrm{C}=$ the concentration of the element in the hybrid magma $(\mathrm{m})$ and mixture poles ( $a$ and $b)$;

$\mathrm{X}=$ the mixture rate.

In the mixing of alkaline mafic (alkali basalt, basanite) and felsic (phonolite, trachyte) magmas from which the different types of antecrysts crystallize, the composition of the hybrid host liquid (represented by the dike matrix) is expected to coincide with the mixing curve at some point between the poles. Figure 11 shows the compositional contrasts given by $\mathrm{Zr} / \mathrm{Y}$ and $\mathrm{La} / \mathrm{Nb}$ ratios between mafic and felsic liquids calculated from antecrysts. Figure 11 also indicates that the calculated liquid composition in equilibrium with the phenocryst population overlaps the dike matrices compositions (after discounting the antecryst cargo influence) as well as their mixing curves. Overlapping is also observed between the composition of the aphanitic phonolites of the western Mantiqueira range (Azzone et al. 2018) and the scattering of equilibrium liquids calculated from B-type antecrysts, corroborating that these antecrysts were crystallized from felsic alkaline magmas.

Therefore, the mixing process modeled between mafic and felsic alkaline liquids (from which the clinopyroxene populations of western Mantiqueira range alkaline dikes derive) replicates the hybrid composition of the hosting matrix. Additionally, this modeling shows that the simplified petrological classification of the antecrysts into two groups (A and $\mathrm{B}$ ) is consistent.

\section{Reconstruction of the magmatic plumbing system}

The mafic macrocryst populations of the magmatic system associated with alkaline dikes of the Mantiqueira range record complex processes, including:

- incorporation of xenocrysts of mantle source region;

- mixing/mingling between mafic and felsic alkaline magmas;

- crystal-liquid fractionation at lower depths.

Figure 12 summarizes a conceptual sketch plumbing system model for the studied bodies, following the petrographic and compositional data offered by xenocrysts and antecrysts. The alkali basalts are responsible for capturing Cr-diopside xenocrysts (A1-subtype), olivine (type 1), and enstatite (D-type). Some xenocrysts are of mantle origin, such as A1-subtype clinopyroxene (compatible with garnet and garnet-spinel lherzolite facies depths), type 1 olivine and, possibly, D-type orthopyroxene (Fig. 12A). Other xenocrysts have affinities with lower crust levels, such as B1- and B2-subtypes of clinopyroxene. In alkali basalt, alkaline lamprophyre and phonolitic tephrite dikes, the complex

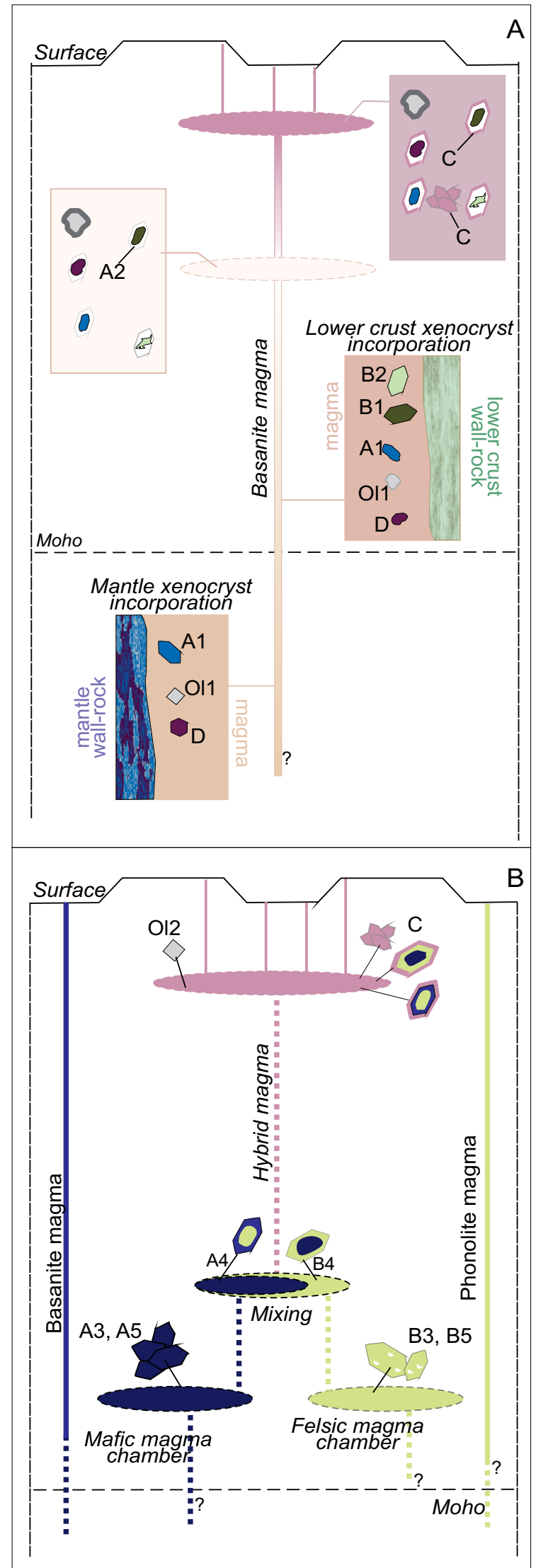

Figure 12. Schematic cartoons of the proposed model for the ascent history of ultrabasic alkaline magmas of the Mantiqueira range following (A) xenocrystic and (B) antecrystic petrographic and compositional data. In $\mathrm{A}$, enlargements of the ascent path show the dominant processes (see text for details) in each level of ascension. In $B$, the complex plumbing system is indicated, considering mixing process between mafic and felsic alkaline magmas during the ascent history. The figure is not to scale. Mineral types follow the description in the main text and table 2 . 
population of clinopyroxene antecrysts is explained by the mixture of mafic and felsic alkaline magmas (Fig. 12B). In this sense, the differences in the chemical evolution of the described antecryst types are compatible with variations in the proportions of mixture between the poles. After these early-stages, xenocrysts and antecrysts are transported and recycled to a new magmatic-stage at lower depths. This shallower stage is well marked by:

- C-type overgrowths in A- and B-type antecrysts and xenocrysts;

- the presence of C-type pyroxene as the main mafic crystal in the matrix or as aggregates with type 2 olivine antecrysts.

Along with the abundance of euhedral clinopyroxene, the glomeroporphyritic texture between Ti-augite and olivine suggests a shallower chamber stage of the magmatic system. The presence of Ti-rich kaersutite and pargasite antecrysts following $\mathrm{Ti}$-augite formation could be related to this shallow chamber environment. This would be the last magmatic-stage prior to the ascent to the final emplacement site along Mantiqueira range escarpments. The complexity of the system is further increased considering the role of more sporadic kaersutite and phlogopite antecrysts, which would require further studies.

An important implication of better understanding the regional scenario is related to the whole-rock geochemical signatures of these lithotypes. Previous studies addressing the whole-rock compositions of primitive dikes in the region (e.g., Thompson et al. 1998, Brotzu et al. 2005, Azzone et al. 2018) made several considerations regarding mantle sources based on incompatible trace elements ratios, including those of Mantiqueira range dikes. Albeit their primitive whole-rock composition, the present study shows that such bodies record mainly open-system petrological processes. Geochemical inferences on mantle sources and their heterogeneities would only be considered robust if the evolution processes were already well constrained and the influence of macrocrysts (their composition and volume) on the overall composition were considered (e.g., Ubide et al. 2015, Menezes et al. 2015). The restricted amount of macrocrysts in alkaline dikes of the Mantiqueira range does not significantly influence these compositions (Menezes et al. 2015, Ambrosio and Azzone 2018). However, the present study shows that the compositions of the matrix (liquids) are compatible with hybrid liquids representative of different contribution rates between primitive (alkali basalt, basanite) and evolved (phonolite, trachyte) pole compositions. Thus, special care should be taken when whole-rock signatures are considered and a detailed petrographic and mineralogical study is recommended to better understand these magmatic types, which, although not very significant in terms of modal amounts, are of great petrological complexity.

\section{CONCLUSIONS}

Based on different chemical approaches and detailed petrographic characterization of the mafic alkaline dikes of the Mantiqueira range, it can be concluded that:

- Among the mafic macrocrysts described, different populations of xenocrysts (type-1 olivine, D-type pyroxene and A1-, B1-, and B2-subtypes of clinopyroxene), antecrysts (type 2 olivine; A2-, A3-, A4-, A5-, B3-, B4-, B5-subtypes, and $\mathrm{C}$-type clinopyroxenes; kaersutite and pargasite; phlogopite), and phenocrysts (C-type clinopyroxene, kaersutite) were characterized;

- For the first time, mantle xenocrysts are reported in the western portion of the Mantiqueira range. The data obtained are of utmost importance to the geology and petrogenesis of the Serra do Mar Alkaline Province, once it confirms mantle regions of garnet- and/or garnet-spinel lherzolite facies as probable magma sources;

- The mixing of mafic and felsic alkaline magmas is indicated and modeled from clinopyroxene antecryst populations of olivine-basalt and lamprophyre alkaline dikes. The matrices of the dikes correspond to hybrid liquids of the mixing of mafic and felsic alkaline magmatic poles;

- The processes of magma mixing and incorporation of xenocrysts (from the mantle source and/or host rocks) efficiently explain the complex petrographic and chemical features present in alkaline mafic magmas of the Mantiqueira range as a Complex Magma Plumbing System.

\section{ACKNOWLEDGMENTS}

This research study was granted by the Fundação de Amparo à Pesquisa do Estado de São Paulo (FAPESP) (2012/06082-6, 2017/03768-8, RGA; 2018/15731-4, LC). JCLS and RGA acknowledge the Brazilian National Research Council (CNPq) for a scholarship (134203/2016$0)$ and for productivity grant (304148/2017-2), respectively. We also thank the analytical support of the technicians of the laboratories of GeoAnalítica-USP facilities. The authors appreciated and acknowledge the helpful comments and suggestions of the reviewers, and the editorial support from the journal.

\section{ARTICLE INFORMATION}

Manuscript ID: 2020-0010. Received on: 02/12/2020. Approved on: 06/01/2020.

J.L. developed her Masters dissertation on this topic and wrote a first draft of the manuscript; R.A. advised J.L. on his Masters studies, wrote parts of the final manuscript, revised and edited the original paper; L.C. wrote some parts of the final manuscript. helped with the discussions and revised the manuscript; V.G. and N.L. participated in data curation and validation, and revised the manuscript.

Competing interests: The authors declare no competing interests. 


\section{REFERENCES}

Akinin V.V., Sobolev A.V., Ntaflos T., Richter W. 2005. Clinopyroxene megacrysts from Enmelen melanephelinitic volcanoes (Chukchi Peninsula, Russia): application to composition and evolution of mantle melts. Contributions to Mineralogy and Petrology, 150(1):85-101. https://dx.doi. org/10.1007/s00410-005-0007-x

Almeida F.F. 1983. Relações tectônicas das rochas alcalinas mesozóicas da região meridional da Plataforma Sul-Americana. Revista Brasileira de Geociências, 13(3):139-158.

Almeida V.V. 2009. Mineralogia e petrologia de xenólitos mantélicos das regiões de Ubatuba (SP) e Monte Carmelo (MG): evidências de fusão parcial e metassomatismo no manto superior do sudeste do Brasil. Master's dissertation, Universidade de São Paulo, São Paulo. Available at: <https://www.teses. usp.br/teses/disponiveis/44/44143/tde-14102009-082110/pt-br.php>. Accessed on: Jun. 30, 2018.

Alves F.R., Ruberti E., Vlach S.R.F. 1992. Magmatismo Meso-Cenozóico da região da Serra da Mantiqueira, SP/MG. Boletim IG-USP, (12):7-9. Available at: <http://ppegeo.igc.usp.br/index.php/bigsp/issue/ view/373>. Accessed on: Jun. 30, 2018.

Ambrosio M.R., Azzone R.G. 2018. The Influence of Crystal and Melt Compositions On the REE+Y Partitioning Between Clinopyroxene and Basanitic/tephritic Melts of Cretaceous Alkaline Magmatism on the southeastern part of the South American Platform, Southeast Brazil. The Canadian Mineralogist, 56(3):303-329. https://doi.org/10.3749/ canmin. 1700024

Aoki K., Kushiro I. 1968. Some clinopyroxenes from ultramafic inclusions in Dreiser Weiher, Eifel. Contributions to Mineralogy and Petrology, 18:326-337. https://doi.org/10.1007/BF00399694

Andrade S., Ulbrich H.H., Gomes C.B., Martins L. 2014. Methodology for the determination of trace and minor elements in minerals and fused rock glasses with laser ablation associated with quadrupole inductively coupled plasma mass spectrometry (LA-Q-ICP-MS). American Journal of Analytical Chemistry, 5(11):701-721. https://doi.org/10.4236/ajac.2014.511079

Armstrong J.T. 1995. Citzaf- a package of correction programs for the quantitative Electron Microbeam X-Ray-Analysis of thick polished materials, thin-films, and particles. Microbeam Analysis, 4(3):177-200.

Asimow P.D., Ghiorso M.S. 1998. Algorithmic modifications extending MELTS to calculate subsolidus phase relations. American Mineralogist, 83(9-10):1127-1132. https://doi.org/10.2138/am-1998-9-1022

Azzone R.G. 2008. Petrogênese do maciço alcalino máfico-ultramáfico Ponte Nova (SP-MG). Ph.D. thesis, Universidade de São Paulo, São Paulo. Available at: <https://teses.usp.br/teses/disponiveis/44/44143/tde02092008-115448/en.php>. Accessed on: Jun. 30, 2018.

Azzone R.G., Enrich G.E.R., Gomes C.B., Ruberti E. 2013. Trace element composition of parental magmas from mafic-ultramafic cumulates determined by in situ mineral analyses: The Juquiá mafic-ultramafic alkalinecarbonatite massif, SE Brazil. Journal of South American Earth Sciences, 41:5-21. https://doi.org/10.1016/j.jsames.2012.07.005

Azzone R.G., Munoz P.M., Enrich G.E.R., Alves A., Ruberti E., Gomes C.B. 2016. Petrographic, geochemical and isotopic evidence of crustal assimilation processes in the Ponte Nova alkaline mafic-ultramafic massif, SE Brazil. Lithos, 260:58-75. https://doi.org/10.1016/j. lithos.2016.05.004

Azzone R.G., Ruberti E., Enrich G.E.R., Gomes C.B. 2009a. Geologia e geocronologia do maciço alcalino máfico-ultramáfico Ponte Nova (SP-MG). Geologia USP Série Científica, 9(2):23-46. http://dx.doi.org/10.5327/ z1519-874x2009000200002

Azzone R.G., Ruberti E., Enrich G.E.R., Gomes C.B. 2009b. Zr-and Ba-rich minerals from the Ponte Nova alkaline mafic-ultramafic massif, southeastern Brazil: indication of an enriched mantle source. The Canadian Mineralogist, 47(5):1087-1103. https://doi.org/10.3749/canmin.47.5.1087

Azzone R.G., Ruberti E., Lopes da Silva J.C., Gomes C.B., Rojas G.E.E., Hollanda M.H.B.M., Tassinari C.C.G. 2018. Upper Cretaceous weakly to strongly silica-undersaturated alkaline dike series of the Mantiqueira Range, Serra do Mar alkaline province: Crustal assimilation processes and mantle source signatures. Brazilian Journal of Geology, 48(2):373-390. http:// dx.doi.org/10.1590/2317-4889201820170089
Batki A., Pál-Molnár E., Jankovics M.É., Kerr A.C., Kiss B., Markl G., Heincz A., Harangi S. 2018. Insights into the evolution of an alkaline magmatic system: An in situ trace element study of clinopyroxenes from the Ditrău Alkaline Massif, Romania. Lithos, 300-301:51-71. https://doi. org/10.1016/j.lithos.2017.11.029

Brotzu P., Gomes C.B., Melluso L., Morbidelli L., Morra V., Ruberti E. 1997. Petrogenesis of coexisting $\mathrm{SiO} 2$-undersaturated to $\mathrm{SiO} 2$-oversaturated felsic igneous rocks: the alkaline complex of Itatiaia, southeastern Brazil. Lithos, 40(2-4):133-156. https://doi.org/10.1016/S0024-4937(97)00007-8

Brotzu P., Melluso L., D’Amelio F., Lustrino M. 2005. Potassic dykes and intrusions of the Serra do Mar Igneous Province (SE Brazil). In: CominChiaramonti P., Gomes C.B. (Eds.). Mesozoic to Cenozoic alkaline magmatism in the Brazilian Platform. São Paulo: Edusp, p. 443-472.

Burchardt S. 2018. Volcanic and Igneous Plumbing Systems: Understanding Magma Transport, Storage, and Evolution in the Earth's Crust. Uppsala: Elsevier.

Bussweiler Y., Foley S., Prevelic D., Jacob D.E. 2015. The olivine macrocryst problem: new insights from minor and trace element compositions of olivine from Lac de Gras Kimberlites, Canada. Lithos, 220-223:238-252. https://doi.org/10.1016/j.lithos.2015.02.016

Cashman K.V., Sparks R.S.J., Blundy J.D. 2017. Vertically extensive and unstable magmatic systems: a unified view of igneous processes. Science, 355 (6331):eaag3055. https://doi.org/10.1126/science.aag3055

Davidson J.P., Morgan D.J., Charlier B.L.A., Harlou R., Hora J.M. 2007. Microsampling and isotopic analysis of igneous rocks: implications for the study of magmatic systems. Annual Review of Earth and Planetary Sciences, 35:273-311. https://doi.org/10.1146/annurev.earth.35.031306.140211

Deer W.A., Howie R.A., Zussman J. 1992. An Introduction to the RockForming Minerals. $2^{\text {a }}$ ed. London: Longman Scientific \& Technical.

Dobosi G., Fodor R.V. 1992. Magma fractionation, replenishment, and mixing as inferred from green-core clinopyroxenes in Pliocene basanite, southern Slovakia. Lithos, 28(2):133-150. https://doi. org/10.1016/0024-4937(92)90028-W

Enrich G.E.R., Azzone R.G., Ruberti E., Gomes C.B., Comin-Chiaramonti P. 2005. Itatiaia, Passa Quatro and São Sebastião Island, the major alkaline syenitic complexes from the Serra do Mar region. In: Comin-Chiaramonti P., Gomes C.B. (Eds.). Mesozoic to Cenozoic alkaline magmatism in the Brazilian Platform. São Paulo: Edusp, p. 419-441.

Ersoy E.Y. 2013. PETROMODELER (Petrological Modeler): a Microsoft ${ }^{\circledast}$ Excel $^{\odot}$ spreadsheet program for modelling melting, mixing, crystallization and assimilation processes in magmatic systems. Turkish Journal of Earth Sciences, 22:115-125. https://doi.org/10.3906/yer-1104-6

Foley S. 1992. Vein-plus-wall-rock melting mechanisms in the lithosphere and the origin of potassic alkaline magmas. Lithos, 28(3-6):435-453. https://doi.org/10.1016/0024-4937(92)90018-T

Foley S., Jacob D.E., O’Neil H.S.C. 2011. Trace element variations in olivine phenocrysts from Ugandan potassic rocks as clues to the chemical characteristics of parental magmas. Contributions of Mineralogy and Petrology, 162:1-20. https://doi.org/10.1007/s00410-010-0579-y

Foley S., Prelevic D., Rehfeldt T., Jacob D.E. 2013. Minor and trace elements in olivines as probes into early igneous and mantle melting processes. Earth and Planetary Science Letters, 363:181-191. https://doi.org/10.1016/j. eps1.2012.11.025

Foley S., Venturelli G., Green D.H., Toscani L. 1987. The ultrapotassic rocks: characteristics, classification, and constraints for petrogenetic models. Earth-Science Reviews, 24(2):81-134. https://doi. org/10.1016/0012-8252(87)90001-8

Garda G.M. 1995. Os diques básicos e ultrabásicos da região costeira entre as cidades de São Sebastião e Ubatuba, Estado de São Paulo. $\mathrm{PhD}$ thesis, Universidade de São Paulo, São Paulo. Available at: <https://teses.usp.br/teses/ disponiveis/44/44135/tde-20032013-160227/pt-br.php>. Accessed on: Jun. 30, 2018. https://doi.org/10.11606/T.44.1995.tde-20032013-160227

Gernon T.M., Upton B.G.J., Ugra R., Yücel C., Taylor R.N., Elliott H. 2016. Complex subvolcanic magma plumbing system of an alkali basaltic maardiatreme volcano (Elie Ness, Fife, Scotland). Lithos, 264:70-85. https://doi. org/10.1016/j.lithos.2016.08.001 
Ginibre C., Wörner G., Kronz A. 2007. Crystal zoning as an archive for magma evolution. Elements, 3(4):261-266. https://doi.org/10.2113/ gselements.3.4.261

Grütter H.S. 2009. Pyroxene xenocryst geotherms: Techniques and application. Lithos, 112(Suppl. 2):1167-1178. https://doi.org/10.1016/j. lithos.2009.03.023

Gualda G.A.R., Vlach S.R.F. 2005. Stoichiometry-based estimates of ferric iron in calcic, sodic-calcic and sodic amphiboles: A comparison of various methods. Anais da Academia Brasileira de Ciências, 77(3):521-534. https:// doi.org/10.1590/S0001-37652005000300012

Guarino V., de' Gennaro R., Melluso L., Ruberti E., Azzone R.G. 2019. The transition from miaskitic to agpaitic rocks as marked by the accessory mineral assemblages, in the Passa Quatro alkaline complex (southeastern Brazil). Canadian Mineralogist, 57(3):339-361. https://doi.org/10.3749/ canmin. 1800073

Irvine T.N.J., Baragar W.R.A.F. 1971. A guide to the chemical classification of the common volcanic rocks. Canadian Journal of Earth Sciences, 8(5):523-548. https://doi.org/10.1139/e71-055

Jankovics M.É., Dobosi G., Embey-Isztin A., Kiss B., Sági T., Harangi S., Ntaflos T. 2013. Origin and ascent history of unusually crystal-rich alkaline basaltic magmas from the western Pannonian Basin. Bulletin of Volcanology, 75:749. https://doi.org/10.1007/s00445-013-0749-7

Jankovics M.É., Harangi S., Kiss B., Ntaflos T. 2012. Open-system evolution of the Füzes-tó alkaline basaltic magma, western Pannonian Basin: constraints from mineral textures and compositions. Lithos, 140-141:25-37. https://doi.org/10.1016/j.lithos.2012.01.020

Janckovics M.É., Taracsák Z., Dobosi G., Embey-Isztin A., Batki A., Harangi S., Hauzenberger C.A., 2016. Clinopyroxene with diverse origins in alkaline basalts from the western Pannonian Basin: Implications from trace element characteristics. Lithos, 262:120-134. https://doi.org/10.1016/j. lithos.2016.06.030

Jerram D.A., Bryan S.E. 2018. Plumbing systems of shallow level intrusive complexes. In: Breitkreuz C., Rocchi S. (Eds.). Physical Geology of Shallow Magmatic Systems. Cham: Springer, p. 39-60.

Jerram D.A., Davidson J.P. 2007. Frontiers in textural and microgeochemical analysis. Elements, 3(4):235-238. https://doi.org/10.2113/gselements.3.4.235

Jerram D.A., Martin V.M. 2008. Understanding crystal populations and their significance through the magma plumbing system. Geological Society of London, Special Publications, 304(1):133-148. https://doi.org/10.1144/ SP304.7

Jochum K.P., Nohl U., Herwig K., Lammel E., Stoll B., Hofmann A.W. 2005. GeoReM: A New Geochemical Database for Reference Materials and Isotopic Standards. Geostandards and Geoanalytical Research, 29(3):333-338. https://doi.org/10.1111/j.1751-908X.2005.tb00904.x

Kahl M., Chakraborty S., Costa F., Pompilio M. 2011. Dynamic plumbing system beneath volcanoes revealed by kinetic modeling, and the connection to monitoring data: An example from Mt. Etna. Earth and Planetary Science Letters, 308(1-2):11-22. https://doi.org/10.1016/j.epsl.2011.05.008

Laporte D., Lambart S., Schiano P., Ottolini L. 2014. Experimental derivation of nepheline syenite and phonolite liquids by partial melting of upper mantle peridotites. Earth and Planetary Science Letters, 404:319-331. https://doi.org/10.1016/j.epsl.2014.08.002

LaTourrette T., Hervig R.L., Holloway J.R. 1995. Trace element partitioning between amphibole, phlogopite, and basanite melt. Earth and Planetary Science Letters, 135(1-4):13-30. https://doi. org/10.1016/0012-821X(95)00146-4

Le Maitre R.W. 2002. Igneous rocks. A classification of igneous rocks and glossary of terms. $2^{\mathrm{a}}$ ed. New York: Cambridge University Press.

Lesnov F.P. 2010. Rare Earth Elements in Ultramafic and Mafic Rocks and their Minerals: Main types of rocks. Rock-forming minerals. London: Taylor \& Francis Group.

Marins G.M. 2012. Estudo do magmatismo máfico de complexos alcalinos do sudeste do Brasil. Master's thesis, Universidade do Estado do Rio de Janeiro, Rio de Janeiro.

Marsh B.D. 2006. Dynamics of magmatic systems. Elements, 2(5):287-292. https://doi.org/10.2113/gselements.2.5.287
McDonough W.F.,SunS. 1995. The composition of theEarth.Chemical Geology, 120(3-4):223-253. https://doi.org/10.1016/0009-2541(94)00140-4

McGee L.E., Smith I.E.M. 2016. Interpreting chemical compositions of small scale basaltic systems: A review. Journal of Volcanology and Geothermal Research, 325:45-60. https://doi.org/10.1016/j.jvolgeores.2016.06.007

Melluso L., Guarino V., Lustrino M., Morra V., de' Gennaro R. 2017. The REE- and HFSE-bearing phases in the Itatiaia alkaline complex (Brazil), and geochemical evolution of feldspar-rich felsic melts. Mineralogical Magazine, 81(2):217-250

Menezes S.G., Azzone R.G., Rojas G.E.E., Ruberti E., Cagliarani R., Gomes C.B., Chmyz L. 2015. The antecryst compositional influence on Cretaceous alkaline lamprophyre dykes, SE Brazil. Brazilian Journal of Geology, 45(1):79-93. http://dx.doi.org/10.1590/23174889201500010006

Morimoto N. 1988. Nomenclature of pyroxenes. Mineralogy and Petrology, 39:55-76. https://doi.org/10.1007/BF01226262

Orejana D., Villaseca C., Paterson B.A. 2006. Geochemistry of pyroxenitic and hornblenditic xenoliths in alkaline lamprophyres from the Spanish Central System. Lithos, 86(1-2):167-196. https://doi.org/10.1016/j. lithos.2005.03.014

Orejana D., Villaseca C., Paterson B.A. 2007. Geochemistry of mafic phenocrysts from alkaline lamprophyres of the Spanish Central System: implications on crystal fractionation, magma mixing and xenoliths entrapment within deep magma chamber. European Journal of Mineralogy, 19(6):817-832. https://doi.org/10.1127/0935-1221/2007/0019-1763

Pilet S., Hernandez J., Villemant B. 2002. Evidence for high silicic melt circulation and metasomatic events in the mantle beneath alkaline provinces: the $\mathrm{Na}-\mathrm{Fe}$-augitic green-core pyroxenes in the Tertiary alkali basalts of the Cantal massif (French Massif Central). Mineralogy and Petrology, 76:39-62. https://doi.org/10.1007/s007100200031

Pilet S., Baker M.B., Stolper E.M. 2008. Metasomatized lithosphere and the origin of alkaline lavas. Science, 320(5878):916-919. https://doi org $/ 10.1126 /$ science. 1156563

Powell R. 1984. Inversion of the assimilation and fractional crystallization (AFC) equations; characterization of contaminants from isotope and trace element relationships in volcanic suites. Journal of the Geological Society, 141(3):447-452. https://doi.org/10.1144/gsggs.141.3.0447

Putirka K.D. 2008. Thermometers and barometers for volcanic systems. Reviews in Mineralogy and Geochemistry, 69(1):61-120. https://doi. org/10.2138/rmg.2008.69.3

Read G., Grutter H., Winter S., Luckman N., Gaunt F., Thomsen F. 2004. Stratigraphic relations, kimberlite emplacement and lithospheric thermal evolution, Quiricó Basin, Minas Gerais State, Brazil. Lithos, 77(1-4):803-818. https://doi.org/10.1016/j.lithos.2004.04.011

Reguir E.P., Chakhmouradian A.R., Pisiak L., Halden N.M., Yang P., Xu C., Kynický J., Couëslan C.G. 2012. Trace-element composition and zoning in clinopyroxene-and amphibole-group minerals: implications for element partitioning and evolution of carbonatites. Lithos, 128:27-45. https://doi org/10.1016/j.lithos.2011.10.003

Riccomini C., Velázquez V.F., Gomes C.B. 2005. Tectonic controls of the Mesozoic and Cenozoic alkaline magmatism in central-southeastern Brazilian Platform. In: Comin-Chiaramonti P., Gomes C.B. (Eds.). Mesozoic to Cenozoic alkaline magmatism in the Brazilian Platform. São Paulo: Edusp, p. 31-56.

Rieder M., Cavazzini G., D'yakonov Y.S., Frank-Kamenetskii V.A., Gottardi G., Guggenheim S., Koval P.V., Müller G., Neiva A.M.R., Radoslovich E.W., Robert J., Sassi F.P., Takeda H., Weiss Z., Wones D.R. 1998. Nomenclature of the micas. Clays and clay minerals, 46(5):586-595. https://doi. org/10.1346/CCMN.1998.0460513

Rock N.M.S., Gwalani L.G., Griffin B.J. 1994. Alkaline rocks and carbonatites of Amba Dongar and adjacent areas, Deccan Alkaline Province, Gujarat, India. 2. Complexly zoned clinopyroxene phenocrysts. Mineralogy and Petrology, 51:113-135. https://doi.org/10.1007/BF01159723

Rosa P.A.S. 2017. Geologia e evolução petrogenética do maciço alcalino de Itatiaia, MG-RJ. PhD thesis, Universidade de São Paulo, São Paulo.

Rosa P.A.S., Ruberti E. 2018. Nepheline syenites to syenites and granitic rocks of the Itatiaia Alkaline Massif, Southeastern Brazil: new geological insights into a migratory ring Complex. Brazilian Journal of Geology, 48(2):347-372. http://dx.doi.org/10.1590/2317-4889201820170092 
Simonetti A., Shore M., Bell K. 1996. Diopside phenocrysts from nephelinite lavas, Napak Volcano, eastern Uganda; evidence for magma mixing. The Canadian Mineralogist, 34(2):411-421.

Streck M.J. 2008. Mineral textures and zoning as evidence for open system processes. Reviews in Mineralogy and Geochemistry, 69(1):595-622. https:// doi.org/10.2138/rmg.2008.69.15

SzabóC.,BodnarR.J. 1998. Fluid-inclusion evidencefor an upper-mantle origin for green clinopyroxenes in late Cenozoic basanites from the Nógrád-Gömör Volcanic Field, northern Hungary/southern Slovaki. International Geology Review, 40(9):765-773. https://doi.org/10.1080/00206819809465237

Thy P. 1991. High and low pressure phase equilibria of a mildly alkalic lava from the 1965 Surtsey eruption: Experimental results. Lithos, 26(3-4):223-243. https://doi.org/10.1016/0024-4937(91)90030-O

Thompson R.N., Gibson S.A., Mitchell J.G., Dickin A.P., Leonardos O.H., Brod J.A., Greenwood J.C. 1998. Migrating Cretaceous-Eocene Magmatismin the Serra do Mar Alkaline Province, SE Brazil: Melts from the Deflected Trindade Mantle Plume? Journal of Petrology, 39(8):1493-1526. https://doi.org/10.1093/petroj/39.8.1493

Ubide T., Arranz E., Lago M., Galé C., Larrea P. 2012. The influence of crystal settling on the compositional zoning of a thin lamprophyre sill: A multi-method approach. Lithos, 132-133:37-49. https://doi.org/10.1016/j.lithos.2011.11.012
Ubide T., Galé C., Arranz E., Lago M., Larrea P. 2014a. Clinopyroxene and amphibole crystal populations in a lamprophyre sill from the Catalonian Coastal Ranges (NE Spain): a record of magma history and a window to mineral-melt partitioning. Lithos, 184-187:225-242. https://doi. org/10.1016/j.lithos.2013.10.029

Ubide T., Galé C., Larrea P., Arranz E., Lago M. 2014b. Antecrysts and their effect on rock compositions: the Cretaceous lamprophyre suite in the Catalonian Coastal Ranges (NE Spain). Lithos, 206-207:214-233. https:// doi.org/10.1016/j.lithos.2014.07.029

Ubide T. McKenna C.A., Chew D.M., Kamber B.S. 2015. High-resolution LA-ICP-MS trace element mapping of igneous minerals: In search of magma histories. Chemical Geology, 409:157-168. https://doi.org/10.1016/j. chemgeo.2015.05.020

Valente S.C. 1997. Geochemical and isotopic constraints on the petrogenesis of the Cretaceous dykes of Rio de Janeiro, Brazil. PhD thesis, Queen's University of Belfast, Belfast.

Vinagre R., Trouw R.A.J., Mendes J.C., Duffles P., Peternel R., Matos G. 2014. New Evidence of a Magmatic Arc in the Southern Brasília Belt, Brazil: The Serra da Água Limpa Batholith (Socorro-Guaxupé Nappe). Journal of South American Earth Sciences, 54:120-139. https://doi.org/10.1016/j. jsames.2014.05.002 